\title{
Comparison for the Production of Essential Oil by Conventional, Novel and Biotechnology Methods
}

\author{
Fardin Ghasemy-piranloo ${ }^{1}$, Fatemeh Kavousi ${ }^{1}$, and Saeideh Dadashian ${ }^{1}$ \\ ${ }^{1}$ Biosphere Technology Company
}

October 20, 2020

\begin{abstract}
Plant essential oils are natural and aromatic compounds that are found in small amounts in plants and have many interesting applications as flavors and fragrances in perfumery, cosmetics, pharmaceutical, food, agriculture, industry and etc. Essential oils can be produced by various techniques including conventional, novel and biotechnology methods. can be considered as a good alternative to conventional methods due to short extraction time, higher efficiency and quality, non-degradable compounds due to heat, no pollution and etc. Recently, due to the limitations and disadvantages of methods of extraction from intact plants, scientists have been trying to move their way to biotechnology methods and make a variety of plant aromatic compounds by microorganisms. In the biotechnology method, there is no any concern about factors such climate conditions, supply shortages, natural disasters, plant diseases and etc. and a product with very high efficiency and quality is obtained.
\end{abstract}

\section{Introduction}

The word essential oil comes from the Greek root "essential". These compounds have a very strong odor and fragrant. most of them are colorless as long as they are fresh and pure. Essential oils evaporate easily at room temperature when exposed to air. [1, 2, 3, 4].

Essential oils are also known as odoriferous oils and can be extracted from various plant sources, for example flower (Jasmine, Rose, Violet and Lavender), leaves (Thymes, Eucalyptus, Salvia), bark (Cinnamon), buds (Clove), herbs, fruits (Orange, Lemon), twigs, seeds (Cardamom), wood (Sandal), rhizome and roots (Ginger) and etc. $[4,5,6]$.

Herbal essential oils are widely used worldwide in industries such as cosmetics, pharmaceutical, food, agriculture, industry and etc. as flavors or fragrances [3, 7]. Most of them have properties such as antibacterial, antioxidant, fungicide, anti-virus, anti-parasite, insect repellent, fragrance, flavors and etc. [7]. So, they have received a lot of attention in various industries. Compounds produced by plants in nature can be classified into two main groups. The main or primary metabolites are those constituents that are present in the whole family of plants and animals and constitute the main elements of life. Including carbohydrates, proteins, lipids and nucleic acids. In plants, there are other metabolic ways that the production of these ways is not completely known to the organism. These compounds are referred to as secondary metabolites and their production way is called secondary metabolism. Essential oils are secondary metabolites of plants [7, 8, 9].

The composition of the essential oils of plants is different due to the influence of factors such as genetics and environment. Also, these compounds vary according to the methods of extraction from plants and how the plant grow [10].

Plant essential oils compounds are composed of relatively low molecular weight organic molecules including carbon, oxygen, hydrogen. Other elements such as nitrogen, sulfur, chlorine and bromine may be rarely found in this compounds [7,11]. Plant essential oils make up a small part (less than 5\%) of plant composition 
mainly composed of terpenes (monoterpenes $\left(\mathrm{C}_{10}\right)$ represent up more than $80 \%$ of the composition of plant essential oils and sesquerpenes $\left(\mathrm{C}_{15}\right)$ ), aromatic compounds (aldehyde, alcohol, phenol, methoxy derivative, and etc.), and terpenoids (isoprenoids) $[4,6,7,12]$.

Compounds of essential oils can be divided into 2 major groups: terpene hydrocarbons and oxygenated compounds. Hydrocarbons consist of carbon and hydrogen atoms arranged in chains. These hydrocarbons can have non-circular, annular and aromatic structure of carbon and hydrogen atoms arranged in chains. These hydrocarbons can have acyclic, alicyclic (monocyclic, bicyclic, or tricyclic), or aromatic Structure [3]. The most common and most chemical compounds are terpenes in essential oil. Terpenes are composed of isoprene units ( 5 carbon units) and the combination of two isoprene units is called a "terpene unit." Plant essential oils also include other compounds such as diterpenes $\left(\mathrm{C}_{20}\right)$, triterpenes $\left(\mathrm{C}_{30}\right)$ and tetraterpenes $\left(\mathrm{C}_{40}\right)$ in low concentration [4, 13]. The second category of plant essential oils is oxygenated compounds including $\mathrm{C}, \mathrm{H}$ and $\mathrm{O}$. Oxygen compounds can be obtained from terpenes, in which case they are called terpenoids for example phenols, alcohols, aldehydes, ketones: esters, oxides, lactones, ethers [4, 6, 12]. The compounds in the essential oils cause varying smell or flavor [3]. Table 1 shows Some of the important plant essential oils and their major constituents [14].

Table 1. Some of the important plant essential oils and their major constituents

\begin{tabular}{|c|c|c|c|c|}
\hline Species & Common name & Family & $\begin{array}{l}\text { Major terpenes and/or } \\
\text { pheny/propanoid }\end{array}$ & $\begin{array}{l}\text { Major oil-producing } \\
\text { organ(s) }\end{array}$ \\
\hline Mentha arvensis & Commint & Lamiaceae & Menthol, Methyl acetate & Leaf \\
\hline Mentha piperata & Peppermint & & Menthone, Menthol, Isomenthone & Leaf \\
\hline Mentha spicata & Spearmint & & Carvone, Carveol & leaf \\
\hline Salvia officinalis & Sage & & Camphor, Thujone & Leaf \\
\hline Odimum basilicum & Sweet basil & & Chavicol, Linalool, Eugenol & Leaf \\
\hline Lavandula officinalis & Lavender & & Geraniol, Linalool & Flower \\
\hline Origanum majorana & Sweet marjoram & & Terpenen-4-ol, Pinene & Leaf and flower \\
\hline Origanum vulgare & Oregano & & Carvacrol, Thymol, g-Terpinene, $p$-Cymene & Leaf \\
\hline Rosmarinus officinalis & Rosemary & & $\alpha \cdot$ pinene, Bornyl acetate, Camphor, 1,8-cineole & Leaf \\
\hline Thymus vulgaris & Thyme & & Thymol, Carvacrol, $g$-Terpinene, $p$-Cymene & Leaf \\
\hline Cymbopogon winterianus & Citronella & Poaceae & Citronellal, Citronellol, Geraniol & Leaf \\
\hline Cymbopogon flexuosus & Lemongrass & & Citral, Geraniol & Leaf \\
\hline Cymbopogon martini & Palmarosa & & Geraniol, Geranyl acetate & Leaf \\
\hline Vetiveria zinzoides & Vetiver & & & Vetiverol Roots \\
\hline Eucalyptus species & Eucalyptus & Myrtaceae & Eugenol, Methyl eugenol & Leaf \\
\hline Syzygium aromaticum & Clove (bud) & & Eugenol, Eugenyl acetate & Bud \\
\hline Melaleuca altenifoli & Tea-tree & & Terpenen-4-ol, Terpinolene & Leaf and twig \\
\hline Rosa damacena & Rose & Rosaceae & Geraniol, Rose oxide & Flower \\
\hline Artemisia апnиа & Qinghasu & Compositeae & Artemisia ketone & Leaf \\
\hline Artemisia dracunculus & French tarragon & & Methyl chavicol & Leaf \\
\hline Pelargonium graveolens & Geranium & Geraniaceae & Geraniol, L-citronellol & Flower and leaf \\
\hline Carum carvi & Caraway & Umbellifereae & Limonene, Carvone & Seeds \\
\hline Matricaria chamomilla & Chammomile & Asteraceae & Azulene & Flower \\
\hline Santalum album & Sandalwood & Santalaceae & Santalol & Stem \\
\hline Coriandrum sativum & Cilantro & Apiaceae & Linalool, E-2-decanal & Leaf \\
\hline Cinnamomum zeylandicum & Cinnamon & Lauraceae & trans-cinnamaldehyde & Bark \\
\hline
\end{tabular}

Due to the small amounts of essential oils in the plant and the significant importance of them, many methods have been developed to determine the amount of these compounds. Two common and important techniques for the analysis of essential oils are chromatography and mass spectrometry. gas chromatography with mass spectrometry (GC-MS) and high performance liquid chromatography (HPLC) and are the most widely used $[7,15,16]$. Gas chromatography-mass spectrometry (GC-MS) has added to the development and improvement in the analysis of essential oils which could be distinguished compounds with very similar chemical structures of each other [17]. In general, Gas chromatography (GC) for the analysis of volatile compounds and liquid chromatography (LC) for Analysis of non-volatile compounds in essential oils used [18].

In addition to essential oils, other aromatic compounds extracted from plants include: concrete (obtained by extraction with non-polar solvents), absolute (obtained by washing concretes in ethanol or methanol and vacuum distilling alcohol away), pomade (obtained by a process known as enfleurage (described in later sections), resinoids (resinoids are extracted from the natural resin material by hydrocarbon solvent. Resinoids are usually derived from dry matter) [17, 19].

Essential oils can be extracted from different plants by various extraction methods. The manufacturing of 
essential oils, and essential oil extraction method are dependent on botanical material used. The another factor for extraction essential oil is state and form of material. One of the important factors that have a great impact on the quality of essential oil is the extraction method. Inappropriate extraction procedure can lead damage the chemical structure of the essential oil, which in turn changes the quality and natural properties of the essential oil [4]. In generally, extraction methods can be divided into two groups: conventional methods (distillation, cold pressing and etc.) and novel methods (supercritical fluid, microwave and etc.). Investigation in novel technologies, in the last decades has led to more efficient extraction processes for example reduction of energy consumption and extraction time, high yield and improvement of essential oils quality. Recently, due to the limitations and disadvantages of methods of extraction from intact plants, large companies are trying to move their way to biotechnology methods and make a variety of plant compounds by microorganisms. By doing this, they have no stress about problems such as climate conditions, supply shortages, natural disasters, plant diseases etc., and a product with very high efficiency and quality is obtained. Production of natural products and volatile through biotechnology can be an appropriate response to consumer demand in relation to the consumption of natural products and move towards "green processes" and environmentally friendly.

In this review, we have tried to explain the production methods of essential oils, including conventional, novel and biotechnology methods, and make a general comparison between them.

\section{Conventional methods}

The conventional methods include distillation, cold pressing, extraction solvent, enfleurage and

maceration process.

\section{Distillation}

The most common method of extracting essential oils worldwide is distillation. During distillation, fragrant plants, release their essential oil through evaporation. When the vapor pressure of liquids is equal to ambient pressure, it is converted to vapor and by indirect cooling with water, condensed the vapor mixture (oil and water). from the condenser, the distilled liquid flows into a separator, where oil separates from water [7, 9, $18,20]$. Types of distillation methods include hydro (water)-distillation, steam distillation, dry distillation and vacuum distillation.

\section{Hydro-distillation}

This method as standard method, is the simplest and cheapest method selected for essential oil extraction from plant material. In this method, the material is immersed in water and the mixture is boiled. The water and essential oil vapor are condensed to an aqueous fraction. from the condenser, distillated flows into a mechanical separator or decanter, where oil separates from water (figure 1). Plant materials must always be immersed in water during the extraction process, so evaporated water must be replaced. This method is used to extract oil from dried flowers and powders. The main problem with this process is that heat destroys unstable and heat-sensitive compounds or causes structural changes. Also, some essential oils are watersoluble and difficult to separate [4, 7, 21, 22, 23]. rose-scented geranium (Pelargonium sp.) [24], germander (Teucrium orientale) [25] and thyme (Thymus vulgaris L.) [26] were extracted by hydro-distillation and their efficiency were compared. 


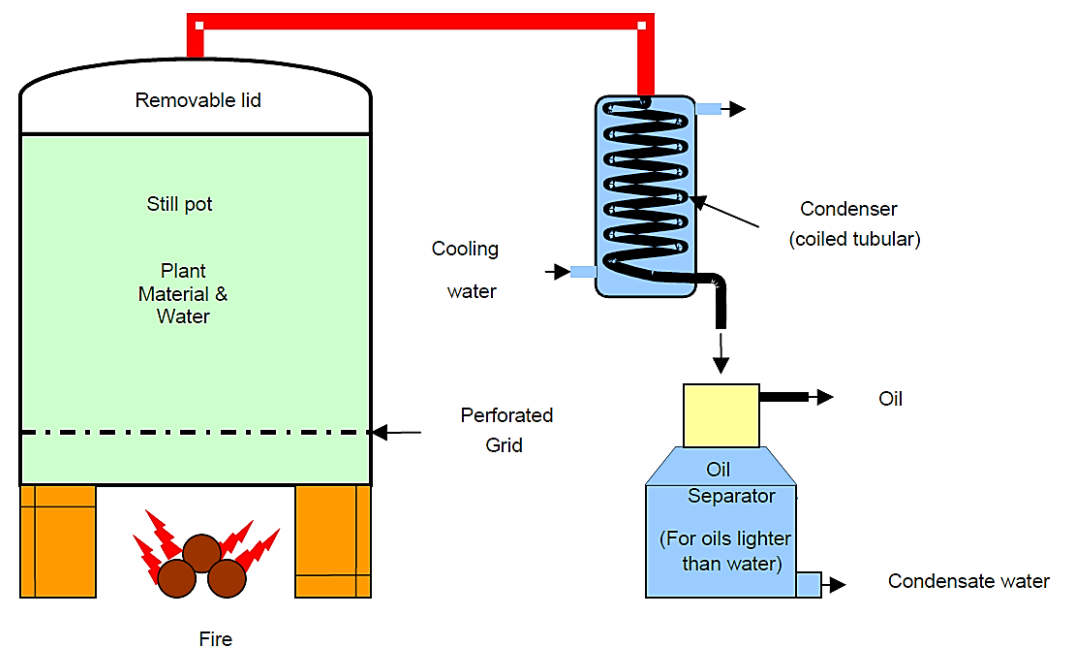

Figure 1. Hydro-distillation of essential oils [23].

The turbo distillation process is the same as water distillation, except that in this method, the mixture is stirred continuously with a stainless steel stirrer at appropriate speed. This method is suitable for coarse raw materials and hard-to-extract (spices, woods). Turbo distillation reduces distillation times and energy consumption and prevents the degradation of volatile compounds compared to aqueous distillation. In fact, it is a kind of green extraction from water distillation (figure 2) [22, 27]. Among the essential oils that were extracted by turbo hydro-distillation method, the extraction of essential oils from Kaempferia galangal can be mentioned [28].
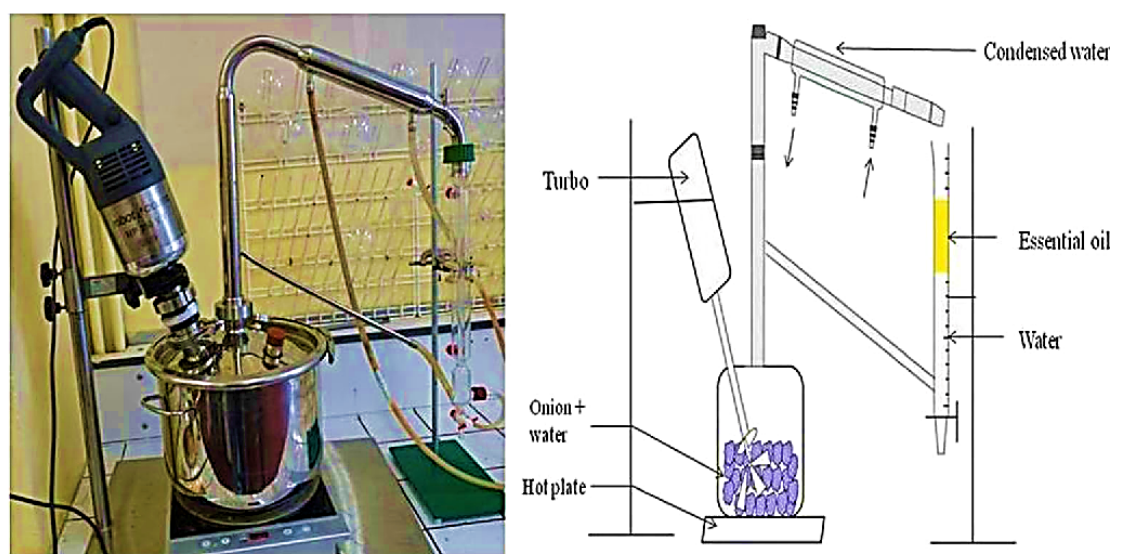

Figure 2. Turbo distillation of essential oils [28].

\section{Water-steam distillation}

The water-steam distillation system is very similar to the water distillation design (figure 3). The plant material is packed into the steel pot sitting on a grill above the boiling water. Due to the heat, the essential oil with water converted to vapor and condensed. After that, the oil and water separated from each other into a mechanical separator or decanter [23]. It is used for dried and fresh plants that do not destroyed due to boiling. In this method, plant materials (dry) are first ground and mixed with water, then the flow 
of steam passes through the wet material [29]. efficiency of essential oil extraction of Cananga odorata flowers by water-steam distillation is reported $43.25 \%$ [30]. Also production of citral oil from lemon grass (Cymbopogon Cytratus) is done by water-steam distillation with $40 \%$ efficiency [31].

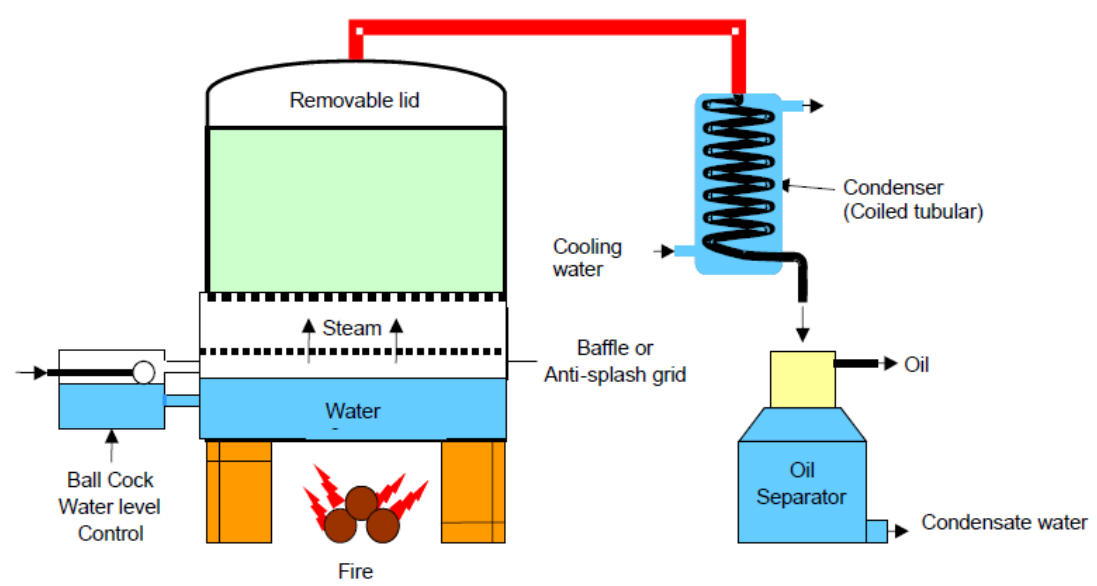

Figure 3. Water-steam distillation of essential oils [23].

\section{Steam distillation}

The most widely used method for extracting plant essential oil is steam distillation [4, 32]. steam distillation is the process of distilling plant material with the steam generated outside the still in a stand-alone boiler (figure 4). As the steam-water distillation system, the plant material is placed on top of a perforated gird above the steam inlet [23]. both water and steam in this method, are utilized, but the plant material is not in direct contact with water and steam generated outside the still in a boiler and flows through a pipe into the bottom of the steel. A mixture of water and oil are vapored and condensed. Finally, the oil is separated from the water by a separator. steam is always fully saturated, wet, and never superheated in this method [7, 33]. Also thermal degradation of components does not occur and amount of steam is adjustable. Of course, this method is more expensive than the hydro-distillation and water-steam distillation. Boutekedjiret is reported extraction of rosemary essential oil by steam distillation [34]. Also E. Cassel succeeded in extracting of rosemary, basil and lavender oils with $0.51 \%, 0.38 \%$ and $0.32 \%(\mathrm{w} / \mathrm{w})$, respectively [35].

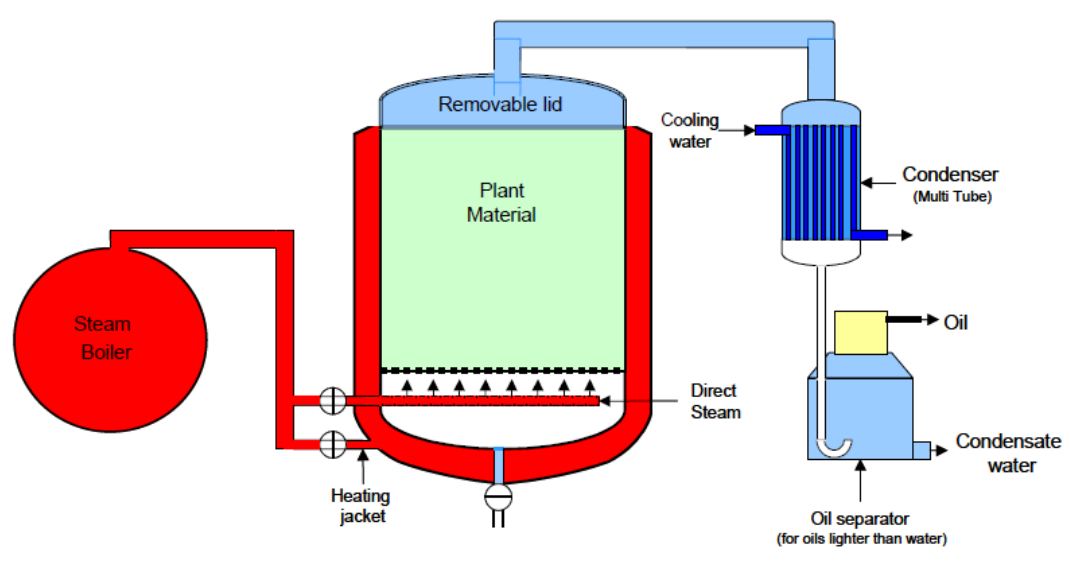


Figure 4. Steam distillation of essential oils [23].

Hydro-diffusion extraction is a type of steam distillation that the only difference with the steam distillation is inlet way of steam into the steel. Steam is entered from the top of plant material, whereas is entered from the bottom in steam distillation. This method is used when the plant material has been dried and is not damaged at boiling temperature [36]. This process can also work under low pressure or vacuum and reduce the steam temperature below $100{ }^{\circ} \mathrm{C}$. This method is superior to steam distillation due to advantages such as shorter isolation times, higher oil yield and less steam used. Hydro-diffusion is also known as down hydro-diffusion or hydro-diffusion and gravity.

\section{Dry distillation}

Dry distillation involves heating in the absence of oxygen and heat is applied usually as a direct flame to the vessel. The high temperatures release essential oils. And the steams of essential oil are condensed to produce essential oil, this process may lead to pyrolysis in the solid. In extraction dry distillation, many organic compounds may decompose. This method is used to extract essential oils with a high boiling point from wood or coal [20].

\section{Vacuum distillation}

The essential oil is obtained from plant materials under a vacuum varying in intensity depending on the material $[37,38]$. The evaporation temperature of the material is lower under vacuum. As a result, materials can be separated by consuming less energy. Vacuum distillation is a suitable method for separating components which have a high boiling point and prevents the destruction of volatiles materials [17]. This method is rarely used to distill oil directly from plant materials.

The table 2 shows a general comparison between conventional distillation methods (hydro-distillation, watersteam distillation steam distillation). In this table, the construction, available temperature, available pressure, plant material suitability, use of Hydro-diffusion, hydrolysis condition and rate of distillation and yield are compared [17, 23].

Table 2-Comparison of Conventional distillation methods

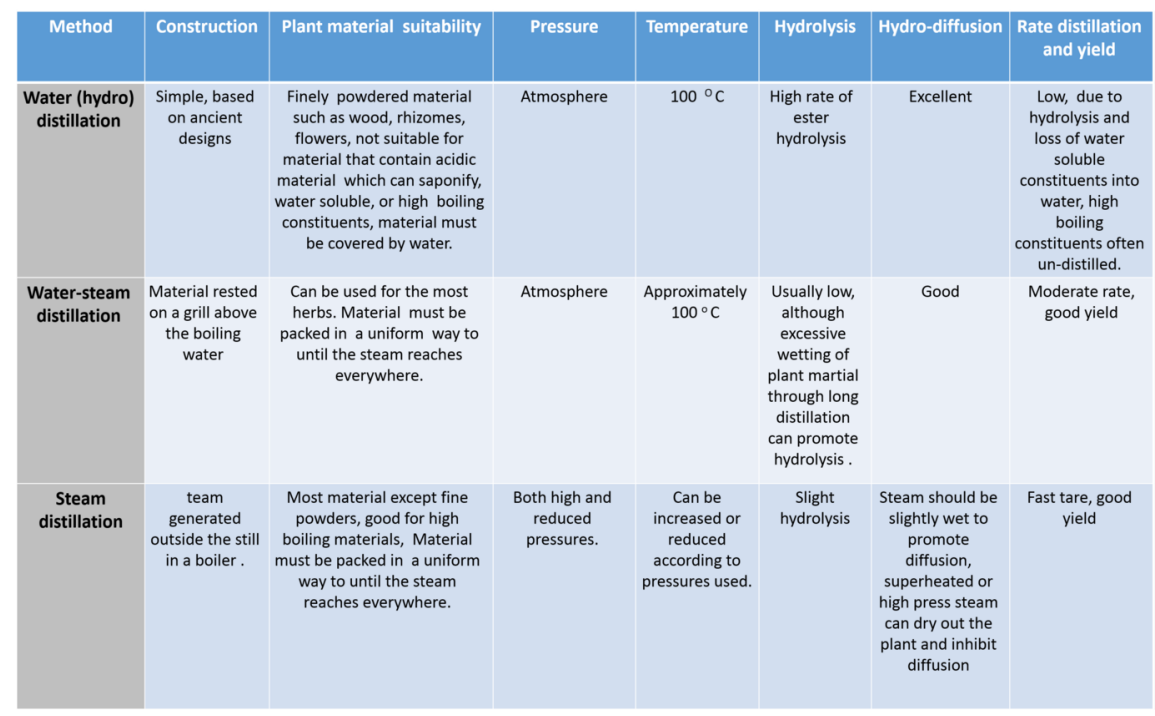

\section{Cold pressing}

Cold pressing is an extraction traditional method specific to citrus species (orange, bergamot, grapefruit, lemon, etc.) to produce essential oil. During extraction, the oil glands break and release the volatile oils. 
The oil glands are located in the fruit rind or outside of the mezocarpe. Figure 5 shows a cross section of a citrus fruit (figure 5). This method is also called Expression [9, 22, 39]. In this physical method, at first, the rinds of the fruits are crushed, then ground and pressed to release the volatile oils in the skin. In this section, a mixture of water and oil is produced simultaneously. Finally, the mixture is allowed to settle. Then the collected oil is washed with water and separated by centrifuge [40]. The figure 6 represents a schematic of the cold pressing [22]. Today the systems of cold pressing can be classified into four categories: "sfumatrici" machines and "speciale sfumatrici", "Pellatrici" machines, "FMC whole fruit process" and "Brown oil extractors (BOEs)" [9,41].

Soto et al. [42] used an enzymatic hydrolysis combined with cold pressing to obtaining borage (Borago officinalis) seed oil for better yield. while Anwar et al. [43] studied the effect of different enzyme on the yield of cold pressing and showed this system has higher yield in compare to without the enzyme.

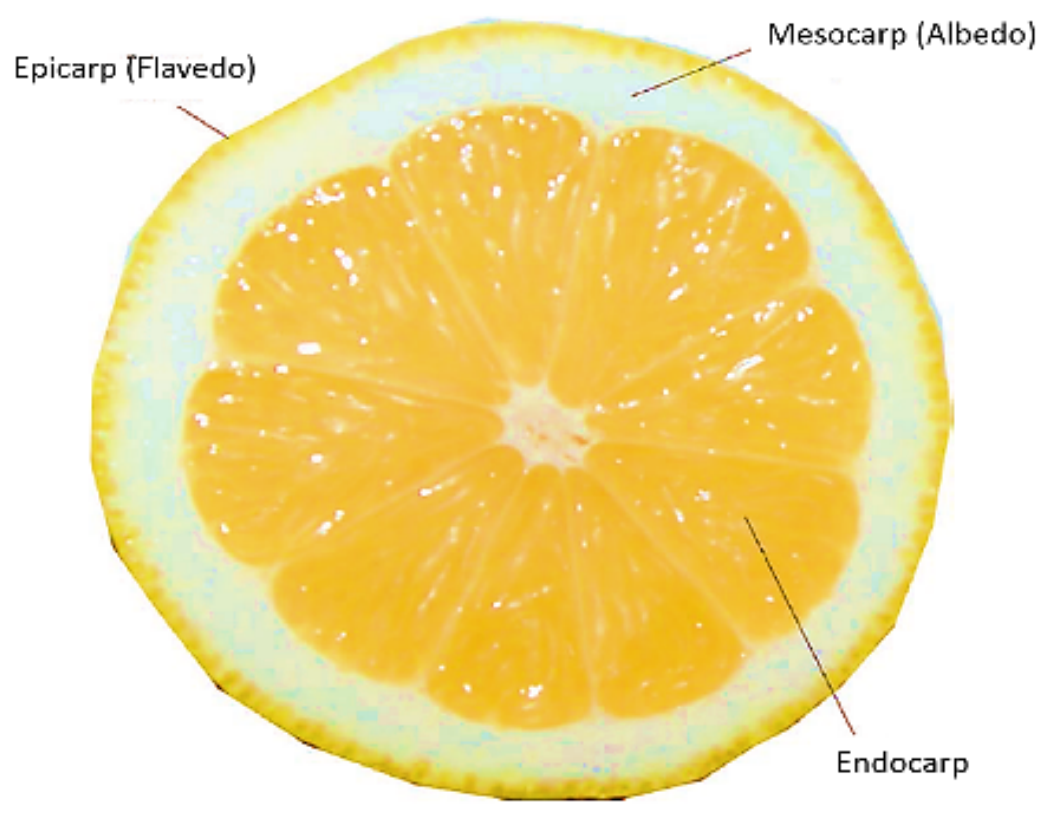

Figure 5. Parts of a citrus fruit [9]

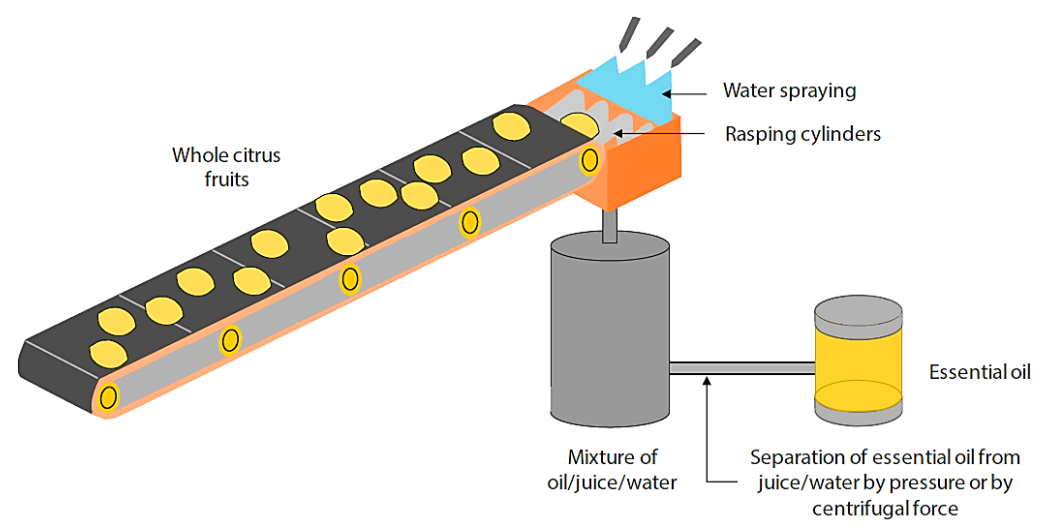


Figure 6. Schematic of cold pressing to obtain essential oil [22].

\section{Extraction solvent}

Solvent extraction method is used to extract non-volatile essential oils [44]. The plant materials are placed in a fresh solvent and is removed non-volatile essential oils of plants. The solvent becomes more enriched with the oil compounds of plants until extraction is complete, followed by filtration. Finally, the filtrate is concentrated by solvent evaporation and a thick residue called "concentrate" is prepared. then the concentrate mixed with alcohol to extract the oil compounds. The alcohol absorbs oil compounds. Followed distillation of alcohol at low temperatures, the concentrated compound is obtained, which is known as the "absolute" and used in perfumery. Solvents used in this method should have a low boiling point, be free of odors and impurities, and should also be inert to oil compositions $[4,45,46]$. Different solvents are used in this method such as: acetone, hexane, petroleum ether, methanol, or ethanol [47, 48, 49].

The most important advantage of this method is the appropriate and low temperature $\left(50{ }^{\circ} \mathrm{C}\right)$. Solvent extraction method has disadvantages such as solvent toxicity in some cases, high solvent consumption, flammability of solvents and the most important factor is the solvent remaining in the final product [22]. Sara Lago [50] is reported improved concentration of citrus essential oil by solvent extraction with acetate ionic liquids. The results showed a great performance of these acetate-based ionic liquids. Extraction essential oil of dried sage (Salvia officinalis) using ethanol-water mixtures have been studied by Nicola E.Durling [51]. This gave an extract including $6.9 \%$ rosmarinic acid (55\% recovery), $10.6 \%$ carnosic compounds $(75 \%$ recovery) and $7.3 \%$ essential oil ( $42 \%$ recovery).

\section{Enfleurage}

This is an old method of extracting essential oils and is not commonly used today. In this method oil or animal fats (usually goat) spread out over glass plates in a frame. flowers or plant material are placed on top of the layer of fat and pressed in. Until the aromatic compounds was imparted to the fat, for days or weeks depending on the species. Followed the oil is filtered to leave a product called "Pomade'. then the absolute is obtained by mix the pomade with alcohol and followed distillation [17, 52]. The depleted material is then replaced by fresh ones until the fat to enrich with aromatic substances [53]. The enfleurage process can be done either "hot" or "cold" way. The only difference in the hot process is that the fats are heated during extraction (figure 7).

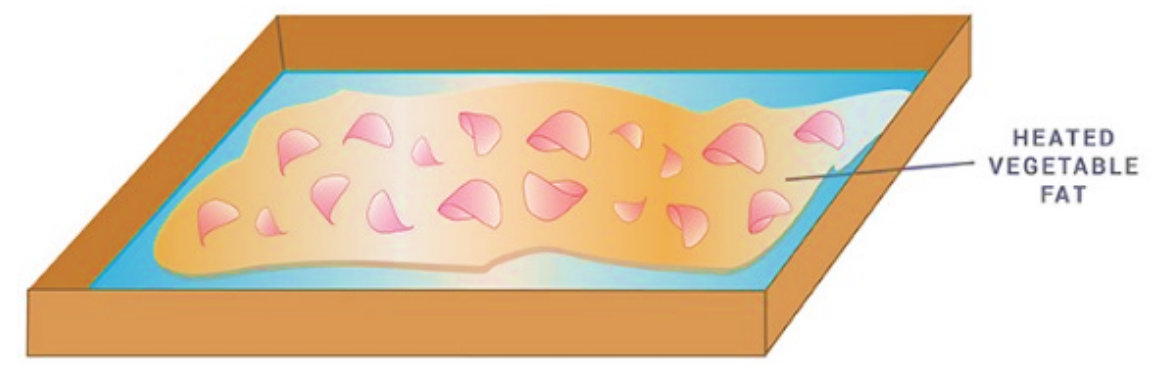

Figure 7. Hot enfleurage process

\section{Maceration process}

Maceration process is a traditional and commonly used method [54]. Macerated oils are referred to as infused oils [18]. Macerated oil has an advantage over distilled oil because it produces more essential oil due to the absorption of larger molecules than those trapped in the distillation process which in turn preserves most of the plant's valuable compounds. Maceration is a variation on enfleurage. In this method, plant material should be as dry as possible because any moisture will cause the oil to rancid and lead to the growth of germs. In maceration process, plant material is finely crushed, or ground into coarse powder and placed in a closed vessel. Solvent (Menstruum) is added. The mixture is allowed to stand for 1 week and is shaken 
occasionally (it depended upon the plant species). The liquid is strained. oil residue (Marc) is pressed to recover any remaining liquid. Strained and pressed liquids are mixed. Finally, liquids are clarified through filtration or subsidence. Maceration method is useful for flowers whose physiological properties are lost rapidly after harvest after their harvest. For example, lily of valley. In the hot maceration process, the plant material crushed, or ground into coarse powder and is immersed in molten fat heated at $45-60{ }^{\circ} \mathrm{C}$ for 1 to 2 $\mathrm{h}$, depending upon the plant species. Therefore, due to heat and immersion in fat, the long enfleurage time is reduced. After each immersion, the fat is filtered and separated from plant material. the fat is separated from waste flowers after 10 to 20 immersions. Finally, absolute of maceration is obtained through the process of extraction and concentration under reduced pressure of fat containing oil [17, 18, 53, 54, 55]. Figure 8 shows a schematic of maceration process (figure 8).

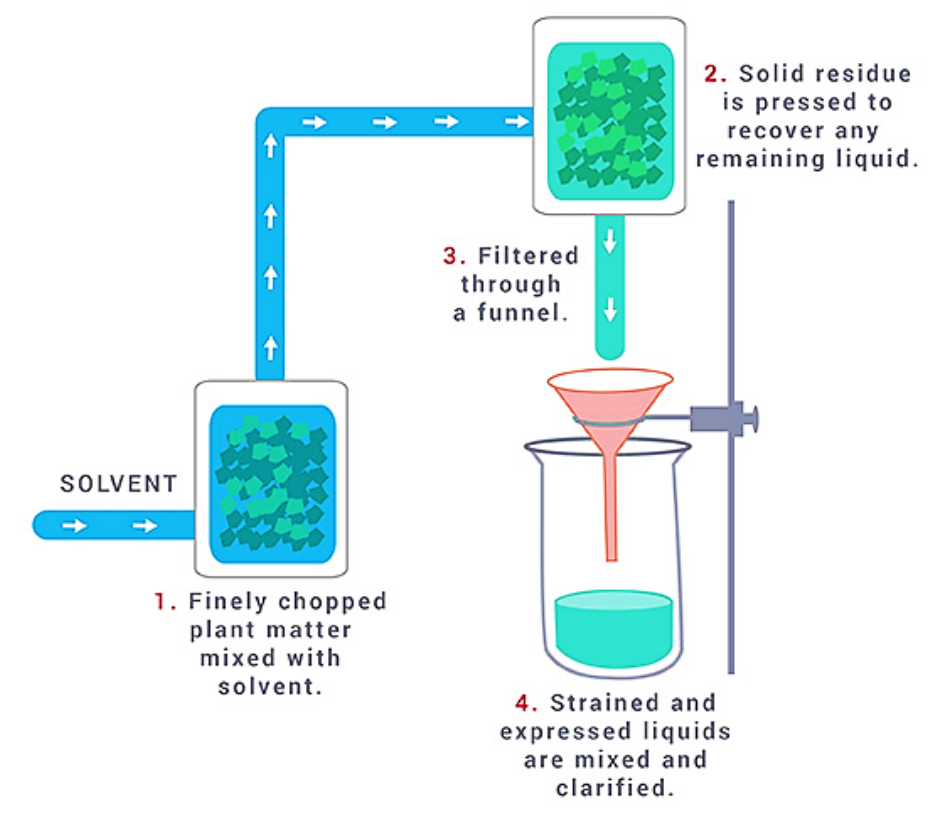

Figure 8. Schematic of maceration process

\section{Novel extraction methods}

Novel extraction methods are also known as green methods. Green extraction can be defined as follows: Green extraction is based on extraction methods that reduce energy consumption, allow the use of alternative solvents and renewable natural products. Also ensure the safety of the process and the production of a quality product. In general, these types of extraction methods have the following characteristics [56].

1. selection of varieties and renewable plant resources.

2. Use an alternative solvent.

3. Reduce energy consumption.

4. Production of co-products instead of waste.

5 . ensure the process is safe, robust and controlled.

6. Production of biodegradable extracts without contamination.

These green methods have led to considering application of new methods include Supercritical fluid extraction (SFE), Subcritical extraction liquids, Enzyme-assisted extraction, Ultrasound-Assisted Extraction (UAE), Microwave-assisted extraction (MAE), (PEF) Pulsed electric field (PEF), Pressurized liquid extraction (PLE) and High voltage electrical discharge (HVED) for the extraction of essential oil.

Supercritical fluid extraction (SFE) 
One of the alternative methods for extracting essential oils is supercritical fluids. SFE is based on the use of solvents in their supercritical state, meaning that they are exposed to temperatures and pressures above their critical points. SCF have a unique property and are between the liquid and gas phases, which depends on the pressure, temperature and composition of the liquids $[4,6]$. The most widely used solvent for this extraction is carbon dioxide, $\mathrm{CO}_{2}$ (figure 9 ). Because it has modest critical conditions $\left(\mathrm{P}_{\mathrm{c}}: 72.9 \mathrm{~atm}\right.$, and $\mathrm{T}_{\mathrm{c}}: 31.2^{\circ} \mathrm{C}$ ), unaggressive for heat sensitive compounds [57], it has no any toxicity and is nonflammable, it is available in high purity at low cost, it can be easily removed from the obtained extract [58], No solvent remains in the final product [59] and etc.

$\mathrm{CO}_{2}$ extracts show some of the properties of essential oils and absolutes. Like essential oils, they have many beneficial therapeutic properties and unlike absolutes, they are not extracted by solvent and instead of chemical solvents, they are extracted using $\mathrm{CO}_{2}$ gas under pressure and at room temperature.

In general, $\mathrm{CO}_{2}$ extracts has excellent quality and better functional with biological activities [60] compared to essential oil produced by hydro-distillation or liquid solvent [61,62]. The high cost of capital and skills required in a supercritical carbon dioxide extraction plant, as well as the wide range of applications of this process, limit it except for large flavor producers. rosemary, fennel and anise essential oils were obtained by supercritical fluid extraction. The results showed that extraction of supercritical fluids to obtain extracts is economically viable. [63]. Supercritical $\mathrm{CO}_{2}$ extraction of essential oil from lavender was performed by E. Reverchon [64]. This compound showed $34.7 \%$ efficiency of the oil.

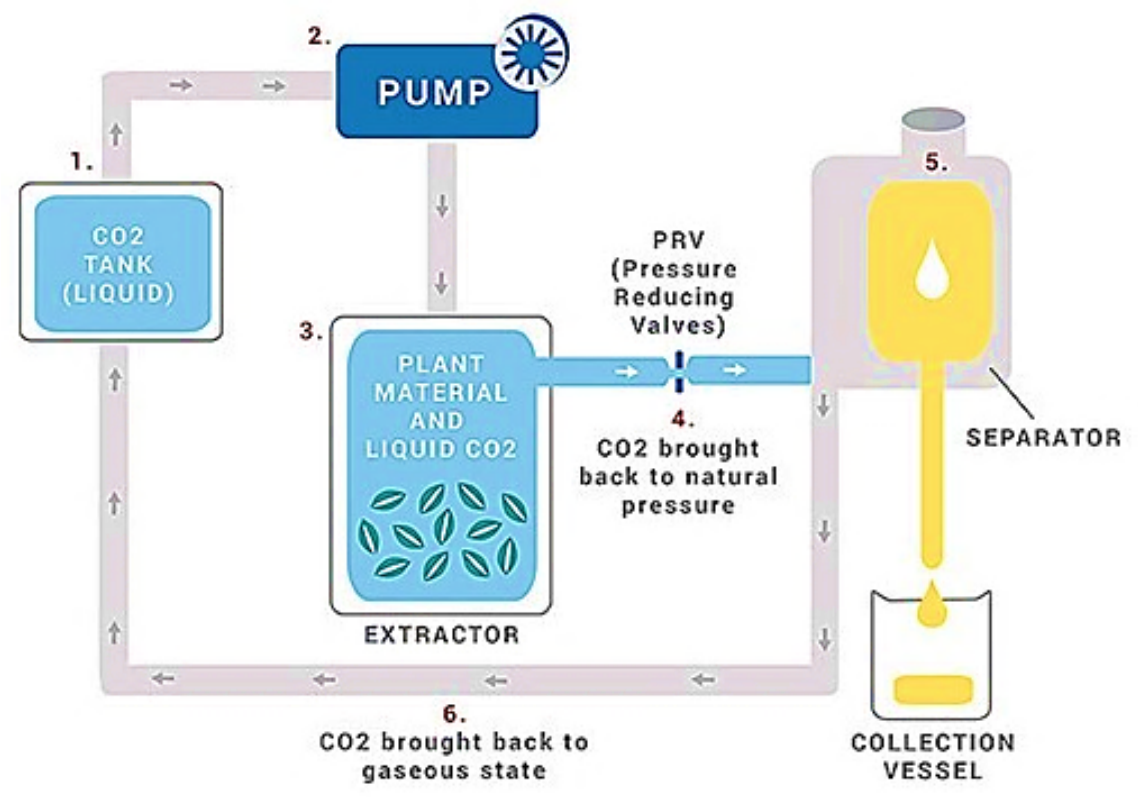

Figure 9. Supercritical fluid extraction (SFE)

\section{Subcritical extraction liquids (SEL)}

Subcritical state is achieved when the pressure is higher than the critical pressure $\left(\mathrm{P}_{\mathrm{c}}\right)$ but the temperature is lower than the critical temperature $\left(\mathrm{T}_{\mathrm{c}}\right)$, or conversely. The most common fluids for this method are water and $\mathrm{CO}_{2}$. low viscosity, density close to the that of the liquids and diffusivity between that of the gas and liquid are good properties of the liquids obtained in this method $[65,66]$. Other positive aspects of using this method are simplicity, low cost and favorable impact on the environment. The most important advantages of this technique over traditional extraction techniques are: shorter extraction time, higher extract quality, lower extraction costs, an environmentally friendly method and low solvent consumption [57]. The subcritical 
state of $\mathrm{CO}_{2}$ occurs when the temperature is between 31 and $55{ }^{\circ} \mathrm{C}$ and the pressure is between $5.5 \mathrm{MPa}$ and 4.7 MPa. In this form, $\mathrm{CO}_{2}$ behaves as a non-polar solvent [67]. The subcritical state of $\mathrm{CO}_{2}$ prevents degradation observed due to temperature during other common extraction methods.

Subcritical water extraction (SWE), also known as "pressurized hot water", has dynamic conditions (pressure high enough to maintain water under liquid state and temperature in the range of 100 to $374{ }^{\circ} \mathrm{C}$ ) [4]. In general, extracts obtained from subcritical carbon dioxide have better quality and functional in comparison to SWE [68]. According to studies, based on a comparison between supercritical $\mathrm{CO}_{2}$ and SWE [69], It was concluded that although the SWE process is cheaper and softer than supercritical $\mathrm{CO}_{2}$ but it is still expensive to operate due to the need for special equipment [70]. The following schematic (figure 10) compares supercritical $\mathrm{CO}_{2}$ with subcritical water [57, 70]. For SWE, temperature of $130{ }^{\circ} \mathrm{C}$ and 20 min extraction time were found optimal for obtaining high content of bioactive compounds. The results of this method were evaluated with other novel methods such as microwave-assisted extraction and showed lower efficiency [71].
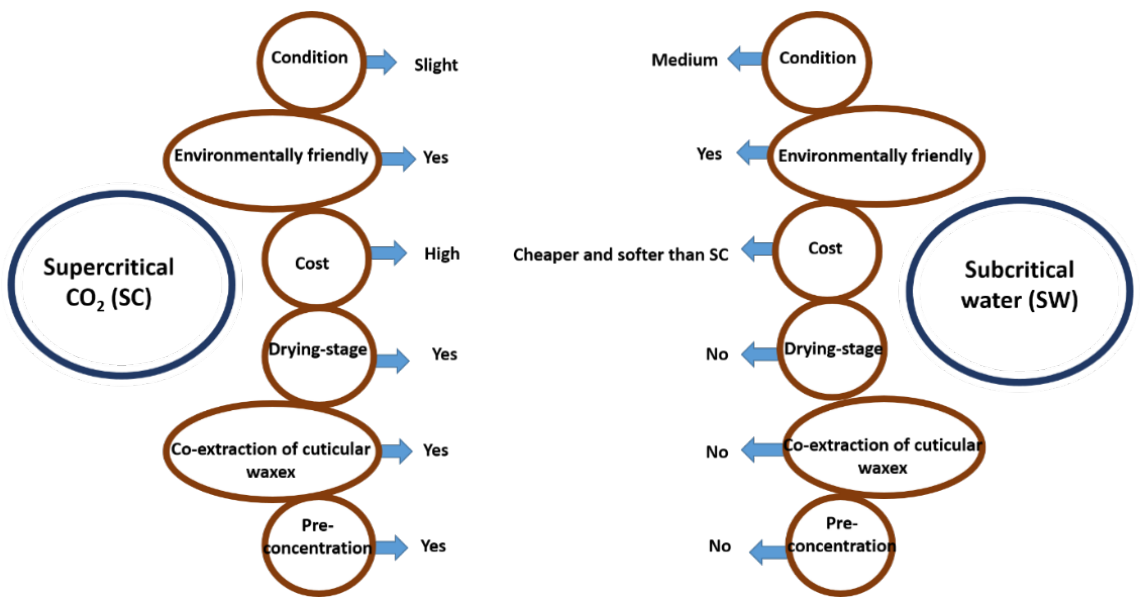

Figure 10. A comparison between supercritical $\mathrm{CO}_{2}$ and subcritical water

\section{Ultrasound assisted extraction (UAE)}

In this method, the plant material is immersed in water or solvent and then exposed to ultrasound. The ultrasonic waves have a frequency of $20 \mathrm{kHz}-1 \mathrm{MH}$ depending on plant species. In this method, the mechanical vibration created by ultrasonic waves causes the walls and membranes of plants to vibrate and rupture. As a result, essential oil droplets are released. in other words, the cell walls are diffused, and once the walls are broken, the essential droplets washed out [6,72]. The size of the plant material is an important factor in this method. The smaller the size of the plant material, the more cells are exposed to the waves [6]. Figure 11 shows Commonly used ultrasonic systems [73].

Compared to traditional methods, the UAE is improving time and temperature extraction and increases the range of solvent selection. It also offers high quality products with higher efficiency. This method is useful for compounds which sensitive to heat. The equipment is relatively simple and inexpensive compared to other new techniques $[6,74]$. For example, citrus flowers of lemon were extracted by UAE. According to the result, the main component was Linalool with $11.3 \%$ efficiency [75].

\section{Enzyme-assisted extraction}

The release of essential oils from plant cells can be done by the green method of using enzymes. This method is based on the ability of enzymes to catalyze reactions, under moderate conditions in aqueous solutions and provides extraction and release of bioactive compounds. Hence enzyme-assisted extraction method is a technique extraction is considered environmentally friendly (figure 12). The enzymes used can be obtained from bacteria, fungi, animal organs and plant extracts. In this method, important factors such as efficiency, 
operating conditions such as time, temperature, $\mathrm{pH}$, the ratio of enzyme to substrate and substrate particle size should be considered. The advantages of this method are: low solvent consumption, increased efficiency and quality. One of the limitations of this method is the high relative cost for the process of large volumes of raw materials, enzyme preparation and the problem of converting process scale to industrial scale (due to the complex and different behavior of enzymes in ambient conditions which varies with factors such as dissolved oxygen content, temperature and material availability) [76]. There are 2 routes, to enzyme-assisted extraction: enzyme-assisted aqueous extraction (EAAE) and Enzyme assisted cold pressing (EACP) [77]. Glycosidics essential oils (bitter almond and mustard essential oil) are obtained by enzyme-assisted extraction [19].

A

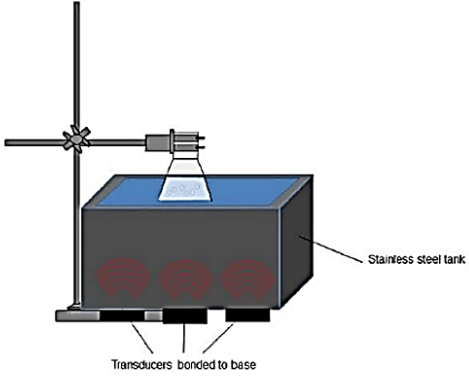

C

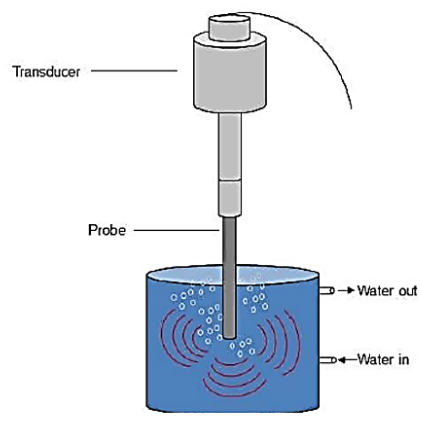

B

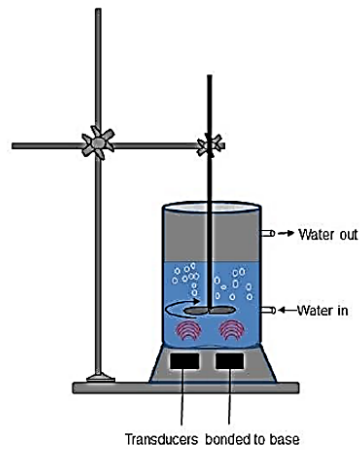

D

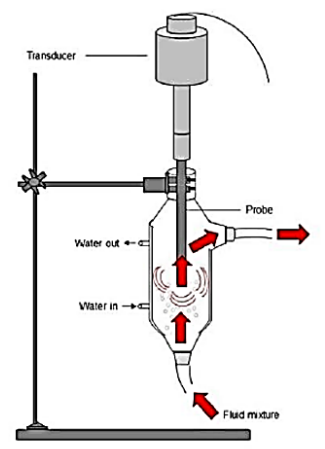

Figure 11. Commonly used ultrasonic systems (A: Ultrasound bath, B: Ultrasound reactor with stirring, C: Ultrasound probe, D: Continuous sonication with ultrasound probe) [73]. 


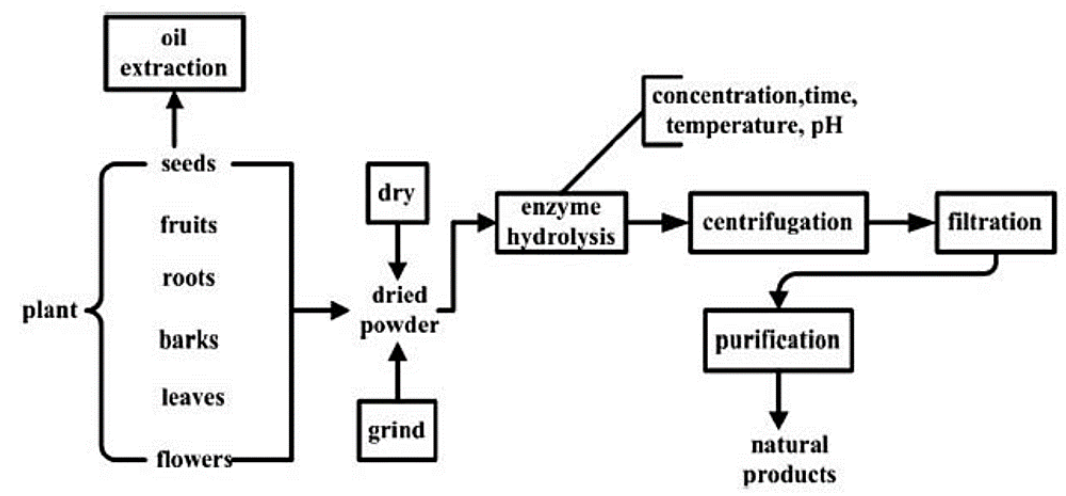

Figure 12. Enzyme-assisted extraction [76]

\section{(PEF) Pulsed Electric Field Extraction}

$\mathrm{PEF}$ is a new and green technology for extracting valuable compounds from wastes and food-agricultural by-products. The pulsed electric field is applied to the material between two electrodes with a pulsed amplitude. In this system, the pulse amplitude changes from $100-300 \mathrm{~V} / \mathrm{cm}$ to $20-80 \mathrm{kV} / \mathrm{cm}$ with low energy $10-20 \mathrm{Kj} / \mathrm{Kg}$. The process takes place at ambient temperature or slightly higher than ambient temperature in less than 1 second (microseconds or milliseconds). In this process, by exposing plant cells to a pulsed electric field, cell membranes are damaged and form temporary or permanent cavities (figure 13). The process of damaging cells and forming cavities with electricity is called electroporation [77, 78].

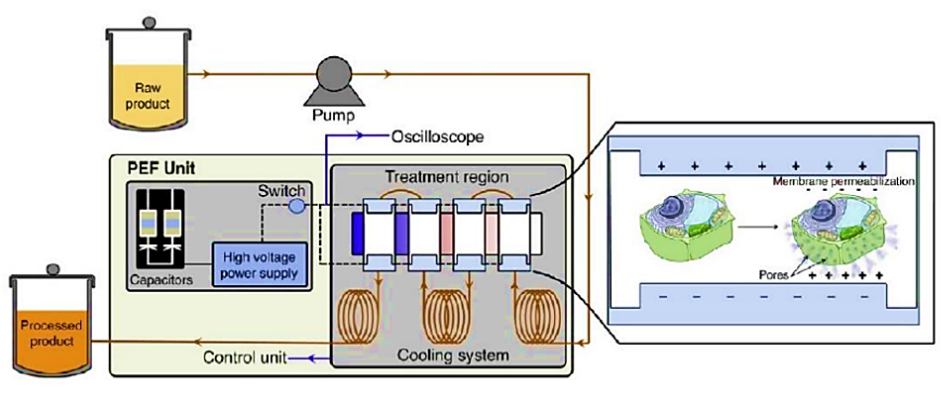

A

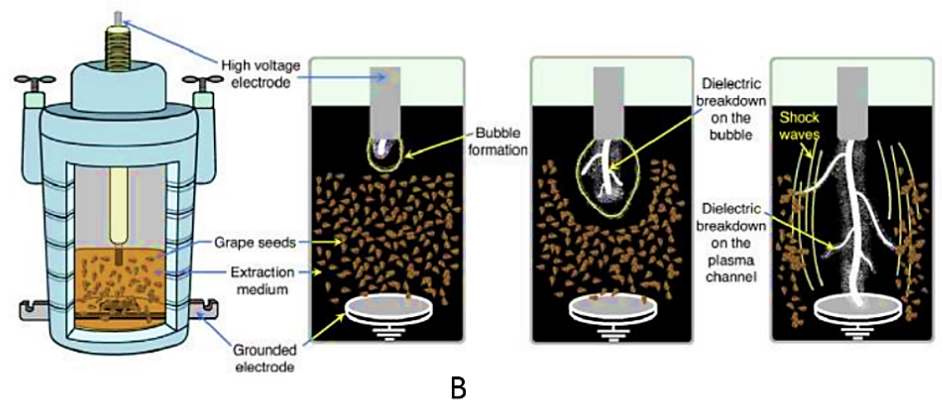

Figure 13. (A) Schematic of a pulsed electric field extraction system (B) Pulse electric field extraction system in scale laboratory for the process of grape seeds and waste and the formation of dielectric breakdown during the process [79]. 


\section{Pressurized liquid extraction (PLE)}

This green method was first proposed by Richter et a (1996) [80] and is considered as an environment-friendly method. The technology is now known by various names: Pressurized liquid extraction (PLE), Accelerated solvent extraction (ASE), Enhanced solvent extraction, Subcritical water extraction (SWE) and Solvent extraction at high pressure [81, 82]. The use high pressure (500-3000 psi) and high temperature (50-200 $\left.{ }^{\circ} \mathrm{C}\right)$ maintain the solvent condition before its normal boiling point which results in reduce the extraction time and the solvent consumption, increases extraction yield and facilitates the process This method is not suitable for compounds sensitive to heat due to high temperature [22, 82, 83]. Water is considered as one of the solvents used in this method that if maintained in a liquid state by pressure, can shows a variety of behaviors such as methanol or ethanol. In general, this technology is not considered as a valuable method on an industrial scale due to the technological challenges [82, 84, 85].

\section{Microwave-assisted extraction (MAE)}

This green method was first proposed in 1986 [86]. Microwaves radiations include X-ray and infrared ray radiations which are characterized by frequencies between $300 \mathrm{MHz}$ to $300 \mathrm{GHz}$. In this method which also called "dielectric heating" or "high-frequency heating", electromagnetic energy due to ionic conductivity and the molecular dipole rotation within the electric field is converted to heat (figure 14). So, the only dielectric materials and solvents with permanent dipoles can be heated under microwave.

In fact, MAE due to electromagnetic waves Causes changes in cell structure. As a result, it differentiates itself from other common methods [87]. In this method, heat transfer occurs inversely from inside to outside compared to normal heating. Parameters such as solvent, temperature and exposure time, pressure, sample viscosity, microwave power output and physicochemical properties of materials affect the quality and efficiency of the final product $[7,88,89,90]$. The advantages of this method over other common methods include reducing the extraction time and volume of solvent, low temperature, energy saving and increasing the yield produced essential oil [7].
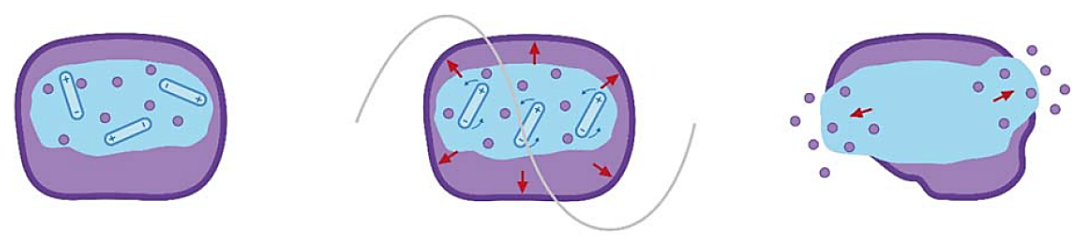

Figure 14. Mechanism of microwave extraction of essential oils based on dielectric heating [22].

Advances in the microwave extraction method led to the development of other methods of microwave extraction. Including: microwave assisted solvent extraction [91], vacuum microwave hydro-distillation [92] microwave hydro-distillation [93], solvent-free microwave extraction [94], microwave accelerated steam distillation [95], microwave hydro-diffusion and gravity (MHG) [36] and microwave-assisted simultaneous distillation-solvent extraction [96]. Figure 15 gives a schematic description of microwave assisted extraction methods [20]. Extraction essential oil by microwave steam diffusion (MSDF) is performed. $125 \mathrm{~g}$ raw material (lavandin) soaked in water during $10 \mathrm{~min}, 500 \mathrm{~W}$, t:15 min, and the yield was obtained 5.4\% [27]. Essential oil of citrus sinensis L. with $5.43 \%$ yield was obtained by microwave steam distillation (MSD) [97].

\section{High voltage electrical discharge (HVED)}

HVED is a green extraction technique and is based on the physical and chemical process which occurs when energy directly in aqueous solution through the plasma channel formed between electrodes that are immersed in water, is interjected $[98,99]$. HVED in liquids causes disrupts cell tissues, resulting in the release of valuable plant compounds. This extraction system can be divided into three different categories: discontinuous, 
continuous and eddy currents systems. The basis of these systems is similar: discharge due to high intensity spatial electric field, cell destruction and increased mass transfer due to various secondary phenomena and their differences were related to the structure of the systems, especially the electrodes, and focus modes of the spatial electric field. This is the process of dielectric decomposition resulting from liquid ionization and occurs with high voltage (30-40 kV) and intensity (approximately $10 \mathrm{kA}$ ) short pulse between two electrodes. The process mechanism summarizes the following steps: Electric pulse generation, Electrostatic discharge, formation Electric arc. Some of the main advantages of HVED technology over conventional methods are: higher extraction rate, reduced process time, higher mass transfer, reduced process temperature and solvent consumption, reduced degradation of compounds sensitive to heat and environmental impacts, saving energy and etc. [100].

The main difference between PEF and HVED is the geometry and composition of their electrodes. Figurec15 gives a description of HVED and PEF extraction methods (figure 16) [78].
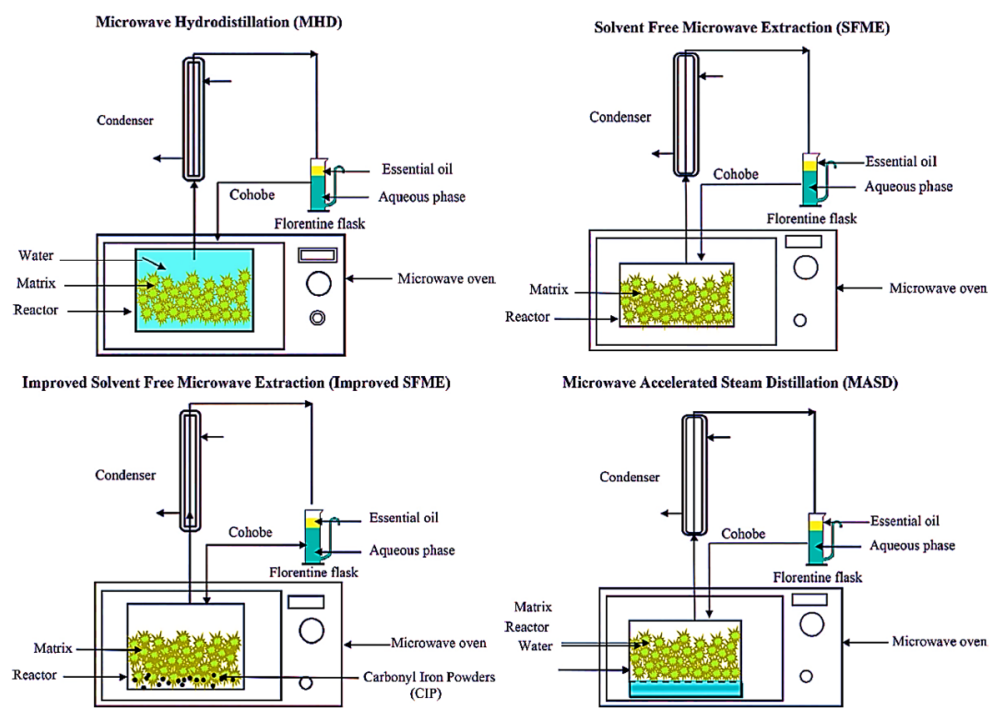

Figure 2 (Continued)
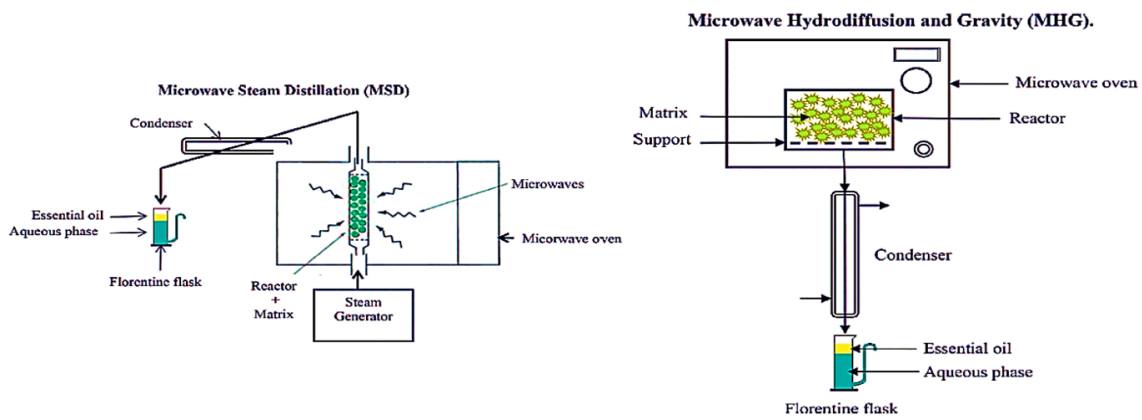

Figure 15. A schematic description of microwave assisted extraction methods [20]. 
Microwave Steam Diffusion (MSDF)

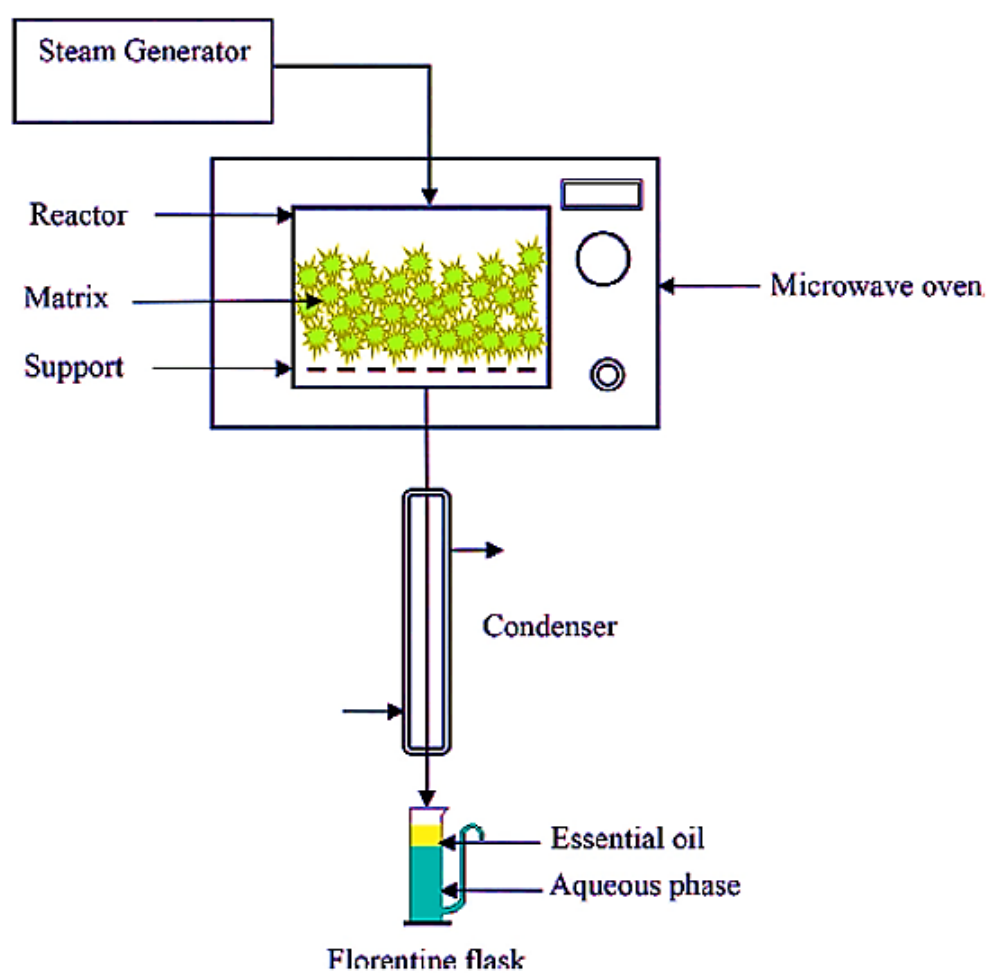

Figure 15 (Continued). A schematic description of microwave assisted extraction methods [20].

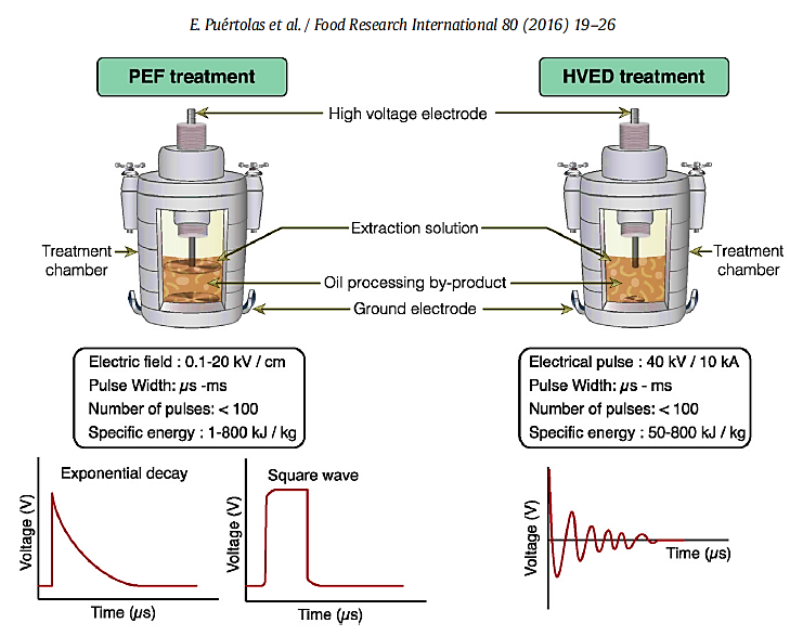

Figure 16. The main process parameters and pulse diagrams used in high voltage electrical discharge (HVED) (PEF) [78]. and pulsed electric field extraction

The table 3 below shows the extraction of essential oils from different types of plants by different extraction method. 
Table 3. Essential oils extracted by different methods and their major components

\begin{tabular}{|c|c|c|c|c|c|}
\hline Essential oil & $\begin{array}{l}\text { Major of } \\
\text { compound }\end{array}$ & plant & $\begin{array}{l}\text { Extraction } \\
\text { technique }\end{array}$ & yield & Ref \\
\hline Oleoresin & Cosmene & Boswellia ameero & hydro-distillation & 34.9 & [101] \\
\hline breu & p-Cymene & breu & hydro-distillation & 51.9 & [102] \\
\hline Satureja thymbra L. & Carvacrol & Thyme-leaved savory & $\begin{array}{l}\text { microwave-assisted } \\
\text { hydro-distillation }\end{array}$ & $\begin{array}{l}38.7 \\
34\end{array}$ & [103] \\
\hline Rosmarinus officinalis & 1,8-Cineol & Rosemary & $\begin{array}{l}\text { steam distillation } \\
\text { hydro-distillation }\end{array}$ & $\begin{array}{l}52.4 \\
31.9\end{array}$ & [104] \\
\hline Ocimum basilicurn & Linalool & Basil & $\begin{array}{l}\text { steam distillation } \\
\text { hydro-distillation } \\
\text { Solvent extraction }\end{array}$ & $\begin{array}{l}48.1 \\
48.2 \\
62.8 \\
\end{array}$ & [105] \\
\hline Origanum glandulosum Desf & sf Thymol & Oregano & $\begin{array}{l}\text { Ivent-free microwave } \\
\text { microwave-assisted } \\
\text { hydro-distillation }\end{array}$ & $\begin{array}{l}81.1 \\
65.4 \\
41.6\end{array}$ & {$[106]$} \\
\hline Citrus limon & Limonene & Lime & $\begin{array}{l}\text { supercritical fluid } \\
\text { hydro-distillation }\end{array}$ & $\begin{array}{l}48.9 \\
47.5 \\
\end{array}$ & [107] \\
\hline Salvia mirzayanii c & $\begin{array}{l}\text { Linalyl acetate } \\
\text { 1,8-cineol }\end{array}$ & Salvia & $\begin{array}{c}\text { supercritical fluid } \\
\text { hydro-distilla }\end{array}$ & $\begin{array}{c}24.6 \\
8\end{array}$ & [108] \\
\hline Syzygium aromaticum & Eugenol & Clove buds & $\begin{array}{l}\text { supercritical fluid } \\
\text { steam distillation } \\
\text { hydro-distillation }\end{array}$ & $\begin{array}{l}58.8 \\
56.2 \\
48.8 \\
\end{array}$ & [109] \\
\hline Aerva javanica seed & Heptacosane & Desert cotton & hydro-distillation & 25.4 & [110] \\
\hline Perilla frutesens & Perillaldehyde & Japanese basil & ultrasound-assiste & 38.8 & [111] \\
\hline
\end{tabular}

Table 4 shows a general comparison between green technologies in the extraction of natural and bioactive compounds, including flavors and fragrances [100, 112].

Table 4. Comparison of green technologies in the extraction of natural compounds 


\begin{tabular}{|c|c|c|c|}
\hline $\begin{array}{l}\text { Extracted } \\
\text { composition }\end{array}$ & Disadvantages & Advantages & Technique \\
\hline $\begin{array}{l}\text { The volatile } \\
\text { compounds }\end{array}$ & $\begin{array}{l}\text { It is not suitable for } \\
\text { the most medicines } \\
\text { and herbal, polar } \\
\text { molecules are not } \\
\text { soluble, expensive }\end{array}$ & $\begin{array}{c}\text { Compared to liquid } \\
\text { extraction: } \\
\text { Less viscosity, more } \\
\text { penetration, better mass } \\
\text { transfer, the } \\
\text { environmentally friendly, } \\
\text { Less process waste and } \\
\text { time, no solvent residue } \\
\text { in product, better } \\
\text { functional, room } \\
\text { temperature, useful for } \\
\text { compounds sensitive to } \\
\text { heat }\end{array}$ & SFE \\
\hline $\begin{array}{l}\text { Phenolic } \\
\text { compounds, } \\
\text { lipids, } \\
\text { chlorophyll and } \\
\text { carotenoids }\end{array}$ & $\begin{array}{l}\text { Ultrasonic frequency, } \\
\text { factors, nominal } \\
\text { power, input power, } \\
\text { system geometry and } \\
\text { size of the plant } \\
\text { material are effective } \\
\text { in increasing } \\
\text { performance. }\end{array}$ & $\begin{array}{l}\text { Less energy and power } \\
\text { consumption, more } \\
\text { extraction efficiency, } \\
\text { less process time and } \\
\text { consumption of } \\
\text { chemicals, useful for } \\
\text { compounds sensitive to } \\
\text { heat }\end{array}$ & UAE \\
\hline $\begin{array}{c}\text { oils and } \\
\text { phytochemicals }\end{array}$ & $\begin{array}{l}\text { high relative cost for } \\
\text { the process of large } \\
\text { volumes, due to the } \\
\text { complex conditions } \\
\text { of the enzyme, the } \\
\text { industrial scale is not } \\
\text { suitable, Particle size } \\
\text {, moisture, hydrolysis } \\
\text { time, operating } \\
\text { conditions should be } \\
\text { controlled. }\end{array}$ & $\begin{array}{l}\text { The environment friendly, } \\
\text { Suitable for extracting } \\
\text { bonded compounds, High } \\
\text { extraction rate, low } \\
\text { solvent consumption, } \\
\text { More extraction efficiency } \\
\text { and quality }\end{array}$ & $\begin{array}{c}\text { Enzyme-assisted } \\
\text { extraction }\end{array}$ \\
\hline $\begin{array}{l}\text { Phytosterols } \\
\text { and } \\
\text { polyphenols }\end{array}$ & $\begin{array}{l}\text { Process parameters } \\
\text { are input energies, } \\
\text { process temperature, } \\
\text { field resistance }\end{array}$ & $\begin{array}{l}\text { Short extraction time and } \\
\text { better efficiency, } \\
\text { The ease of refinement of } \\
\text { extracted materials, } \\
\text { Less environmental } \\
\text { impacts, } \\
\text { Less energy consumption, } \\
\text { ambient temperature or } \\
\text { slightly higher than } \\
\text { ambient temperature }\end{array}$ & PEF \\
\hline
\end{tabular}

Table 5. (Continued) Comparison of green technologies in the extraction of natural compounds 


\begin{tabular}{|c|c|c|c|}
\hline $\begin{array}{l}\text { Extracted } \\
\text { composition }\end{array}$ & Disadvantages & Advantages & Technique \\
\hline $\begin{array}{c}\text { Phytosterols and } \\
\text { polyphenols }\end{array}$ & $\begin{array}{l}\text { Process parameters are } \\
\text { input energies, process } \\
\text { temperature, field } \\
\text { resistance }\end{array}$ & $\begin{array}{l}\text { Short extraction time } \\
\text { and better efficiency, } \\
\text { The ease of refinement } \\
\text { of extracted materials, } \\
\text { Less environmental } \\
\text { impacts, } \\
\text { Less energy } \\
\text { consumption, ambient } \\
\text { temperature or slightly } \\
\text { higher than ambient } \\
\text { temperature }\end{array}$ & PEF \\
\hline $\begin{array}{l}\text { Food industry- } \\
\text { agricultural waste } \\
\text { for phytochemical } \\
\text { extraction }\end{array}$ & $\begin{array}{l}\text { High equipment costs and } \\
\text { is not suitable for samples } \\
\text { Weighing more than } 100 \\
\text { grams, not considered as a } \\
\text { valuable method on an } \\
\text { industrial scale due to the } \\
\text { technological challenges }\end{array}$ & $\begin{array}{l}\text { Suitable for solid } \\
\text { samples, It is more } \\
\text { suitable for polar } \\
\text { compounds than SFE, } \\
\text { Less extraction time } \\
\text { and solvent } \\
\text { consumption, increases } \\
\text { extraction yield, not } \\
\text { suitable for compounds } \\
\text { sensitive to heat }\end{array}$ & PLE \\
\hline $\begin{array}{c}\text { Rapid extraction } \\
\text { of natural } \\
\text { compounds, } \\
\text { especially } \\
\text { polyphenols }\end{array}$ & $\begin{array}{l}\text { Equipment is expensive, } \\
\text { Operation is more difficult } \\
\text { than UAE, They are less } \\
\text { environmentally friendly } \\
\text { due to the use of organic } \\
\text { solvents, Less extraction } \\
\text { efficiency for non-polar } \\
\text { compounds, not suitable } \\
\text { for compounds sensitive } \\
\text { to heat, parameters such as } \\
\text { solvent, temperature and } \\
\text { exposure time, pressure, } \\
\text { sample viscosity, } \\
\text { microwave power output } \\
\text { and physicochemical } \\
\text { properties of materials are } \\
\text { important. }\end{array}$ & $\begin{array}{l}\text { Better quality and } \\
\text { higher selectivity, } \\
\text { higher extraction } \\
\text { efficiency, less } \\
\text { extraction time and } \\
\text { volume of solvent, } \\
\text { energy saving, } \\
\text { Compared to SFE, the } \\
\text { operation is simpler and } \\
\text { more economical. }\end{array}$ & MAE \\
\hline Polyphenols & $\begin{array}{c}\text { Less selectivity than PEF, } \\
\text { their feasibility for } \\
\text { industrial scale or pilot has } \\
\text { not been studied yet. }\end{array}$ & $\begin{array}{l}\text { Consume less energy } \\
\text { than new methods such } \\
\text { as MAE and } \\
\text { UAE, less time, } \\
\text { consume less solvent, } \\
\text { less penetration } \\
\text { temperature }\end{array}$ & HVED \\
\hline
\end{tabular}

\section{Cohobation system}

In the distillation method after the oil has been separated from water, the condensed water which called hydrosol [113] can be recycled and reused for another distillation process and never runs out. This process is called "Cohobation" (figure 17 [114]). It is believed that this will controls the loss of water-soluble oxygen compounds in hydrosol. It is due to the reused water is saturated with dissolved constituents and further dissolution constituents are prevented. It is worth noting that the cohobation method is not recommended for high temperatures (above $100{ }^{\circ} \mathrm{C}$ ), because in the case of continuous and direct contact of an oxygenated 
element with heat, the possibility of degradation and hydrolysis will have promoted $[54,55,115]$. This type of system is a kind of continuous system and reduces extraction time and costs.

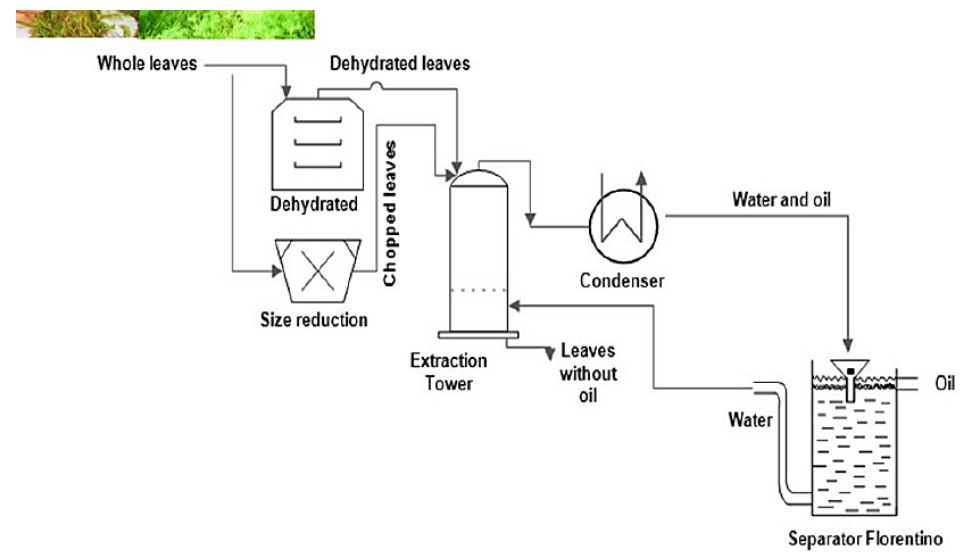

Figure 17. The water-steam distillation method by cohobation for extraction essential oil [114].

There is other type of continuous systems known as continuous systems. In the late 20th century, essential oil producers were forced to load and unload steel after loading and finishing the process regularly. So they set out to create a process that could produce essential oils continuously. In such a way that plant materials are slowly loaded into the upper steel and exit from the bottom. In this method, the whole biomass is in contact with steam and ensures the optimal extraction of essential oil. This method is not suitable for inflorescences, fruits and roots [9].

\section{Biotechnology for the production of essential oil}

As mentioned in the previous sections, volatiles are natural compounds that have gained commercial interest due to their flavor and fragrance properties. The concentration of the most desirable volatiles in essential oils is very low, about less than 10\% (sometimes even less than 1\%) [116]. Plant essential oils are usually obtained through extraction intact plants [117] such as distillation, solvents, carbon dioxide, and etc. or by the methods of chemical synthesis. Each of them has its drawbacks. Chemical synthesis often leads to the production of a mixture of products that have an approximate natural flavor quality. Also, this method is not one of the natural and environmentally friendly [116]. Common extraction methods, in addition to being costly, have problems such as: weather conditions including monsoon, drought, or even by volcano, supply shortages, natural disasters, plant diseases, low yield and etc. [117, 118]. Therefore, due to the limitations and disadvantages of methods of extraction from intact plants or chemical synthesis, scientists are trying to move their way to biotechnology methods and make a variety of plant compounds by microorganisms. In the new biotechnology method which is a kind of green method, in addition to being environmentally friendly and no contamination of the process, there are no more problems mentioned and the product is obtained with very high efficiency and quality. Production of natural products and volatile through biotechnology can be an appropriate response to consumer demand in relation to the consumption of natural products and move towards "green processes" and environmentally friendly. One of the major applications of biotransformation is the production of biotechnology products that are usually synthesized by chemical methods. Bio-methods include volatile production through tissue and cell cultures, hairy roots cultures, culture of microorganisms, biotransformation, metabolic engineering. Various biotechnological methods for the production of volatiles are discussed below:

\section{De novo Production of volatile compounds through Tissue and Cell Cultures}

One of the most important techniques in the industrial production of volatile compounds is plant cultivation. The techniques used in this field are mainly: cell cultures, tissue cultures, hairy roots cultures, microorganism 
cultures.

\section{Cell cultures}

It seems each cultured cell has all the genetic information of the parent plant and therefore has the ability to produce a range of chemicals found in the parent plant [8]. Through this culture, the desired volatile compound can be prepared. Some plants are rare, slow-growing or difficult to grow, so the in vitro under controlled condition is expected to accelerate biomass propagation and provide the essential oil [119]. The yield of this method is influenced by the factors of nutrients and growth regulators of the culture medium such as: sugar, nitrogen, phosphate, growth regulators, precursors and suitable culture medium [120]. But the compounds obtained by this method have low efficiency $(0.01-0 / 1 \mathrm{~g} / \mathrm{l}$ day.) [119]. The reason for the reduction in the production of plant compounds by cell cultures is not yet clear. [116]. So in general, this method does not seem to be a promising method, even with effective agents.

\section{Tissue cultures}

Due to the fact that secondary metabolites are produced more in differentiated tissues of plants, an attempt was made to provide volatile compounds through cultures and differentiated organs of plants such as root stems and etc. [121]. The method of preparing volatile compounds through hairy roots culture is described below.

\section{Hairy roots culture}

Hairy root culture is a type of plant tissue culture for produce of volatile compounds [122]. The formation of hairy root in plants or hair-like root structures is actually the result of a plant disease caused by a gramnegative bacterium called "Agrobacterium rhizogenesis". These roots are used as a source for the production of aromatic and volatile substances [123]. Basically, the importance of hair roots is due to their rapid growth without the need for an external auxin [8] and their rapid growth compared to conventional roots. They produce volatile compounds at levels and patterns similar to natural roots, but secondary metabolites or volatile compounds are also produced in the airy parts of the plant. The efficiency of this method is higher than cell culture and by the ingress of abiotic or biotic elicitors in the culture medium, this efficiency can be further increased [116].

\section{Microorganisms culture}

Another biotechnology method for the synthesis of volatiles is the culture of micrograms. Microorganisms (such as bacteria, fungi, algae, ...) are more potent than plant cells in bioreactor conditions [116]. Of course if a substrate biochemically more immediate to the volatile compound, or an immediate precursor with the raw substrate is used in the culture medium, the efficiency will increase. In this case, the method is similar to biotransformation, which will be explained in the next section. for example, $0.4 \mathrm{~g} / 1$ 2-phenylethanolwhich has a rose-like aroma can be produced by Kluyveromyces marxianus [124]. also $2.8 \mathrm{~g} / \mathrm{l}$ vanillin was achieved by cultured Aspergillus niger [125].

The table 6 presents a list of some of the volatile compounds produced by cell, hairy roots, and microorganism cultures.

\section{Biotransformation}

Biotransformation is a chemical modification performed by an organism on a chemical compound. in other words, microorganisms through specific chemical reactions can cause special changes in some compounds, this process is called biotransformation. In this method, either the whole-cell of the microorganism or the isolated enzymes of the microorganism is used. The advantages of this method makes it relatively superior compared to various chemical synthesis processes. include high purity of the product, minimal side reactions and balanced process conditions, high efficiency, economic efficiency, ability to produce compounds that are difficult with traditional synthesis methods, environmentally friendly and proprietary. 
The techniques used in this field are mainly: Biotransformation by plant cultures and microorganisms, Biotransformation by isolated enzymes. Each of which is briefly explained in the next section:

Table 6. A list of some of the volatile compounds produced by cell, hairy roots, and microorganism cultures.

\begin{tabular}{|c|c|c|c|c|c|}
\hline \multirow{6}{*}{ 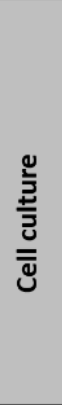 } & Plant & Microorganism & substrate & Product & Ref \\
\hline & Vanilla planifolia & - & - & Vanillin & {$[126]$} \\
\hline & Smyrnium perfoliatu & - & - & $\alpha$-Pinene & [127] \\
\hline & Coleonema album & - & - & Monoterpenes & {$[128]$} \\
\hline & $\begin{array}{l}\text { Artemisia dracunculus } \\
\text { (tarragon) }\end{array}$ & - & - & $\begin{array}{l}\text { phenylpropenes of the } \\
\text { essential oil }\end{array}$ & {$[129]$} \\
\hline & $\begin{array}{l}\text { Mentha piperita } \\
\text { (peppermint) }\end{array}$ & - & - & Mint oil components & {$[130]$} \\
\hline \multirow{4}{*}{ 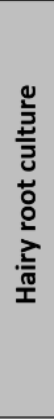 } & Cucumis melo & - & - & $\begin{array}{l}\text { 2-Hexenal as main } \\
\text { ingredient }\end{array}$ & {$[131]$} \\
\hline & Pimpinella anisum & - & - & $\begin{array}{l}\text { Yield of essential } \\
\text { oil comparable to } \\
\text { that of normal plant }\end{array}$ & [132] \\
\hline & Ambrosia trifida & - & - & $\begin{array}{c}\text { Essential oil of roots was } \\
\text { similar to that } \\
\text { of normal roots }\end{array}$ & [133] \\
\hline & $\begin{array}{l}\text { Anethum graveolens } \\
\text { (dill) }\end{array}$ & - & - & $\begin{array}{c}\text { Essential oil yield was only } \\
0.02 \% \text {, compared } \\
\text { to } 0.06 \%, 0.3 \% \text { and } 2 \% \text { of } \\
\text { normal plant root, } \\
\text { leaf and fruits, respectively }\end{array}$ & [134] \\
\hline \multirow{5}{*}{ 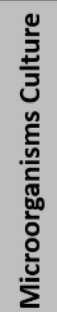 } & - & Aspergillus oryzae & castor oil & $\mathrm{g}$-Decalactone, $0.86 \mathrm{~g} / \mathrm{l}$ & [135] \\
\hline & - & Aspergillus nige & $\begin{array}{l}\text { Rice bran oil (4 } \\
\text { g/l ferulic acid) }\end{array}$ & $2.8 \mathrm{~g} / \mathrm{I}$ Vanillin & [146] \\
\hline & - & $\begin{array}{c}\text { Kluyveromyces } \\
\text { marxianus }\end{array}$ & $\begin{array}{l}\text { Grape must + } \\
\text { Phe }\end{array}$ & 2 phenylethanol, $0.4 \mathrm{~g} / \mathrm{l}$ & [124] \\
\hline & - & $\begin{array}{l}\text { Sporobolomyces } \\
\text { odorous }\end{array}$ & $\begin{array}{l}\text { Hydrolysed } \\
\text { castor oil }\end{array}$ & $\mathrm{y}$-Decalactone, $5.5 \mathrm{~g} / \mathrm{l}$ & [137] \\
\hline & - & $\begin{array}{l}\text { Stigmatella } \\
\text { aurantiaca }\end{array}$ & Agar cultures & $\mathrm{C}_{10}$ volatile ketones & {$[138]$} \\
\hline
\end{tabular}

\section{Biotransformation by plant cultures and microorganisms}

Biotransformation by plant cultures and microorganisms is a good method based on biotechnology for the preparation of volatile compounds that have shown superior to compounds produced in cell cultures.

In biotransformation, an intermediate compound precursor is incorporated into the culture medium, which is bio-transformed or bio-converted to volatile compounds by enzymatic activities. The efficiency of this method is much higher than those which a precursor is not used in the culture medium. But it should be noted that cheap precursors should be searched and used to produce valuable products [116]. For example, $10 \mathrm{mg} / \mathrm{l}$ vanillin was obtained on ferulic acid substrate by cultured Capsicum annuum [139]. Citronellol can be obtained by biotransformation of citronellal by the Peganum harmala [140]. Also The biotransformation of ricinoleic acid by Candida sorbophila can produce up to $40 \mathrm{~g} / \mathrm{l}$ ts-decalactone [141].

This method, in addition to positive aspects, also has negative aspects. Such volatiles do not dissolve easily in aqueous medium. There are some solutions to this problem agents facilitating dissolution can be used (above a threshold concentration is inhibited cell growth). Even high concentrations of the product itself can be toxic and inhibitory to cells growth. As a result, continuous addition of substrate at non-harmful concentrations and removal of the product were developed. Among these methods, the pervaporation method [142] and inserting a volatile binder compound is most commonly used. The issue of trapping and isolating volatile 
compounds produced in the culture medium, has been discussed by Georgiev et al [143] and Ramachandra and Ravishankar [8]. For example, $\beta$-cyclodextrins are water-soluble molecules with a hydrophobic interior and hydrophilic exterior that with proper modification, can trap the product in their cavities.

\section{Biotransformation by isolated enzymes}

Isolated enzymes typically have higher biotransformation rates than cell culture-based methods. But the cost of isolating the enzyme plays an important role in using that enzyme to produce volatiles [144]. Enzymes have a high selectivity and minimize the production of undesirable by-products [145]. However, most studies have been done by whole-cells systems rather than isolated enzymes (7\%) [146]. Although this method has been significant extent [147], but only in cases of biological transmission, volatiles are present. The use of isolated enzymes for biotransformation depends on the availability of the enzyme for the desired conversion reaction, $\mathrm{pH}$, optimum temperature conditions, solvent and substrate. The nature of the enzyme, the type of biotransformation reaction and the need for a cofactor are the determining factors of the method of using the enzyme. In order to facilitate the separation of the product and the catalyst recycling, the use of immobilizing the enzyme is preferred [148].

The table 7 and 8 present a list of some of the volatile compounds produced by biotransformation of plant cultures, microorganisms and isolated enzymes.

\section{metabolic engineering}

Metabolic engineering of metabolic paths is most promising and the newest path for volatile production. Metabolic engineering is the use of genetic engineering to modify the metabolism of an organism to increase the cells' production of a certain substance $[116,149]$. Metabolic engineering, can produce the fragrance and flavors in much larger quantities without need to the rare plant [117]. The use of genetically engineered strains was first reported in 2010 when oil extraction from Pogostemon cablin (Patchouli) was severely deficient. Because it was reported that the rainy weather in Indonesia caused the destruction of medicinal shrubs. Also, other natural problems, such as volcanic eruptions and earthquakes exacerbate supply problems. As a result, in order to solve these problems and supply shortages, scientists began to engineer the genetics of the strains to produce the fragrances of the Patchouli plant. In addition, fragrances of bitter orange, grapefruit, rose and sandalwood were produced using genetically modified. [150].

Table 7. Some of the volatile compounds produced by biotransformation of plants or microorganisms

\begin{tabular}{|c|c|c|c|c|}
\hline \multirow{7}{*}{ 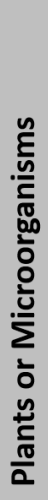 } & Plant/Microorganism & Substrate & Product & Ref \\
\hline & Capsicum annuum & $\begin{array}{l}\text { Ferulic acid, } \\
2.5 \mathrm{mM}\end{array}$ & Vanillin, $10 \mathrm{mg} / \mathrm{l}$ & {$[151]$} \\
\hline & Rosa sp. (roses) & Geraniol & Nerol, citronellol & {$[152$} \\
\hline & $\begin{array}{l}\text { Botryodiplodia theobromae } \\
\text { (Mucor fungus) }\end{array}$ & $\begin{array}{c}\text { (+)-Valencene } \\
\text { (sesquiterpene), } \\
0.4 \mathrm{~g} / \mathrm{l}\end{array}$ & Nootkatone & {$[153$} \\
\hline & Rhodococcus opacus & Limonene & Carveol, carvone & {$[154]$} \\
\hline & Fungi and algae & $\beta$-lonone & $\begin{array}{l}\text { Hydroxyl and oxo } \\
\text { derivatives }\end{array}$ & {$[155$} \\
\hline & Fragaria sp. (strawberry) & $\alpha$-Ketovalerat & Butanal, butanol & {$[156]$} \\
\hline
\end{tabular}

Table 8. Some of the volatile compounds produced by biotransformation of isolated enzymes 


\begin{tabular}{|c|c|c|c|c|}
\hline \multirow{6}{*}{ 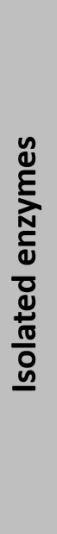 } & Isolated enzyme & Source & Product & Ref \\
\hline & $\begin{array}{c}\text { Lipoxygenase/hydroperoxide } \\
\text { lyase }\end{array}$ & $\begin{array}{l}\text { Apple pomace, } \\
\text { crude mixture }\end{array}$ & $\begin{array}{l}\text { Production of hexanal and } \\
\text { 2,4-decadienal from } \\
\text { unsaturated fatty acids. }\end{array}$ & {$[157]$} \\
\hline & $100 \mathrm{kDa}$ cut-off extract & Tomato fruits & $\begin{array}{c}5 \mu \mathrm{g} / \mathrm{min} \text { hexanal from } \\
16 \mathrm{mM} \text { linoleic acid }\end{array}$ & [158] \\
\hline & Enzyme mix & $\begin{array}{l}\text { Citrus } \\
\text { poonensis } \\
\text { fruit peel }\end{array}$ & $\begin{array}{c}30 \% \text { of limonene was } \\
\text { converted to terpineol, } \\
\text { linalool, and linalool oxide }\end{array}$ & [159] \\
\hline & Amine oxidase & $\begin{array}{l}\text { Aspergillus } \\
\text { niger }\end{array}$ & $\begin{array}{l}\text { Production of vanillin from } \\
\text { vanillamine }\end{array}$ & {$[160]$} \\
\hline & Germacrene A hydroxylase & $\begin{array}{l}\text { Cichorium } \\
\text { intybus }\end{array}$ & $\begin{array}{l}\text { Production of nootkatone } \\
\text { from valencene }\end{array}$ & {$[161]$} \\
\hline
\end{tabular}

\section{Genetic engineering of microorganisms}

Microorganisms, such as bacteria and yeasts that are not normally unable to synthesize a particular compound, are genetically engineered to improve the synthesis of volatiles or to produce new compounds. Produce volatiles in commercially worthwhile quantities by genetically modified microorganisms, would be a great success in biotechnology. For example, using metabolic engineering, the scientists succeeded in producing a synthetic banana smell using the bacterium E. coli [117]. By Yarrowia lipolytica microorganism, Acyl-CoA oxidase genes pox1, pox3 disrupted, and ts-decalactone, $0.35 \mathrm{~g} / \mathrm{l}$ from methyl ricinoleate was observed [162]. Vanillin can be produced at $5 \mathrm{~g} / \mathrm{l}$ by E. coli carrying the 3-deoxyarabino-heptulosonic acid 7 -phosphate synthase gene [163].

\section{Genetically engineered plants}

Genetically modified plant, the DNA of them has been modified using genetic engineering methods. Genetically modified plants have been engineered for scientific research, to production of special product, improvement of plant resistance, increase of plant production and yield and creation of advanced products [164]. For example, Antisense suppression, 10-100-fold more methyl benzoate was observed by Dianthus caryophyllus (carnation) with Flavanone-3-hydroxylase gene [165]. Arabidopsis thaliana genetically engineered by $\beta$-Farnesene synthase gene for Synthesis of (E)- $\beta$-farnesene [166].

\section{The biotech companies that cooperation to produce fragrance and flavoring products}

Nowadays, in the perfume industry, the many big companies participate with each other and cooperation with biotech companies such as Royal DSM or Ginko Bioworks worldwide in order to produce natural flavoring compounds with high quality and efficiency that are involved in producing the microbial based perfumes and flavors from abundant sugar feed-stocks by fermenting sugars. Among these, companies Allylix and Evolva can be mentioned which cooperation, synthesized valencene (a sesquiterpene that is an aroma component of valencia oranges), nootkatone (a natural organic compound, a sesquiterpenoid, and a ketone that is the most important and expensive aromatic of grapefruit), vanillin (is obtained from the extraction of vanilla beans, but today, due to the scarcity and high cost of extraction, synthetic vanillin is more widely used), artificial sweeteners such as stevia and etc. by biotechnology methods. Other companies include Isobionics, Givaudan, Firmenich, International Flavors \& Fragrances (IFF), Robertet which have improved their way 
to the production of natural compounds with high purity and quality towards new biotechnological methods [117].

The table 9 is presented a general comparison of conventional, novel and biotechnology methods.

Table 9. A general comparison of conventional, novel and biotechnology methods

\begin{tabular}{|c|c|c|c|}
\hline Aspect & Conventional & Novel & Biotechnology \\
\hline Environmentally friendly & $\begin{array}{c}\text { Some methods such as } \\
\text { solvent extraction, No }\end{array}$ & Yes & Yes \\
\hline Quality and yields & Low & $\begin{array}{c}\text { More than } \\
\text { conventional }\end{array}$ & $\begin{array}{c}\text { Some method, } \\
\text { Excellent }\end{array}$ \\
\hline Thermal decomposition & Some methods, Yes & No & No \\
\hline Processing time & Long & Short & Short \\
\hline Energy consumption & High & Low & No \\
\hline Harmful and expensive & Some methods such as & No & No \\
\hline solvents & solvent extraction, Yes & No & Yes \\
\hline Need to raw material & Yes & Yes & Low \\
\hline conditions & Low & High & \\
\hline
\end{tabular}

\section{Conclusion}

Plant essential oils are natural and aromatic compounds that are found in small amounts in plants and have many interesting applications as flavors and fragrances in perfumery, cosmetics, pharmaceutical, food, agriculture, industry and etc. Research on essential oils extraction methods has aroused great interest for scientists. as evidenced in this review, essential oils can be produced by various techniques including conventional, novel and biotechnology methods. Novel or green methods can be a good alternative to conventional methods due to their advantages such as higher efficiency and quality, short extraction time, non-degradable compounds due to heat, no pollution and etc. But due to the problems that are observed in common and even new green methods, including climate conditions, supply shortages, natural disasters, plant diseases and etc. recently scientists have chosen biotechnology methods for the preparation of natural compounds. In this method, in addition to the fact that there are no problems of the other extraction methods, finally, a high quality and efficient product is obtained. Production of natural products and volatile through biotechnology can be an appropriate response to consumer demand in relation to the consumption of natural products and move towards "green processes" and environmentally friendly.

\section{Acknowledgement}

Financial support from biosphere technology company is acknowledged. Company management, Dr. Fardin Gheasemi Piranloo is gratefully appreciated for his kind scientific and technical supports.

\section{Reference}

[1] Bullerman, L. B., F. Y. Lieu, and Sally A. Seier. "Inhibition of growth and aflatoxin production by cinnamon and clove oils. Cinnamic aldehyde and eugenol." Journal of Food Science 42.4 (1977): 1107-1109. 
[2] Jaimand, K., and M. B. Rezaee. "Investigation extraction by two different apparatus and effects of essential oils on content and constituents of Tripleurospermum disciforme (CA Mey) Schultz-Bip." In Natural Sciences (2003).

[3] Burt, Sara. "Essential oils: their antibacterial properties and potential applications in foods - a review." International journal of food microbiology 94.3 (2004): 223-253.

[4] Tongnuanchan, Phakawat, and Soottawat Benjakul. "Essential oils: extraction, bioactivities, and their uses for food preservation." Journal of food science 79.7 (2014): R1231-R1249.

[5] Svoboda, K. P., and R. I. Greenaway. "Investigation of volatile oil glands of Satureja hortensis L. (summer savory) and phytochemical comparison of different varieties." The International Journal of Aromatherapy 4.13 (2003): 196-202.

[6] El Asbahani, A., et al. "Essential oils: from extraction to encapsulation." International journal of pharmaceutics 483.1-2 (2015): 220-243.

[7] Reyes-Jurado, Fatima, et al. "Essential oils: antimicrobial activities, extraction methods, and their modeling." Food Engineering Reviews 7.3 (2015): 275-297.

[8] Rao, S. Ramachandra, and G. A. Ravishankar. "Plant cell cultures: chemical factories of secondary metabolites." Biotechnology advances 20.2 (2002): 101-153.

[9] Hüsnü Can Bașer, K., and G. Buchbauer. "Handbook of essential oils: science, technology, and applications." Handbook of essential oils: science, technology, and applications. Ed. 2 (2015).

[10] Talanda, Colin Erlo. The design, construction and testing of a mobile essential oil distillation unit . Diss. 2005.

[11] Williams, David G. The chemistry of essential oils: an introduction for aromatherapists, beauticians, retailers and students. Micelle, 2008.

[12] Bakkali, Fadil, et al. "Biological effects of essential oils-a review." Food and chemical toxicology 46.2 (2008): 446-475.

[13] Mohamed, Amal A., Gehan A. El-Emary, and Hanaa F. Ali. "Influence of some citrus essential oils on cell viability, Glutathione-S-transferase and lipid peroxidation in Ehrlich ascites carcinoma cells." Journal of American Science 6.10 (2010): 820-826

[14] Nagegowda, Dinesh A., and Natalia Dudareva. "Plant biochemistry and biotechnology of flavor compounds and essential oils." Med Plants Biotechnol from Basic Res Ind Applications (2007): 469-492.

[15] Teranishi, Roy, Emily L. Wick, and Irwin Hornstein, eds. Flavor chemistry: thirty years of progress . Springer Science \& Business Media, 1999.

[16] Cserháti, Tibor. Chromatography of aroma compounds and fragrances . Springer Science \& Business Media, 2010.

[17] Hunter, Murray. Essential oils: art, agriculture, science, industry and entrepreneurship . Nova Science Publishers, Incorporated, 2010.

[18] Malik, Sonia, ed. Essential Oil Research: Trends in Biosynthesis, Analytics, Industrial Applications and Biotechnological Production. Springer, 2019.

[19] Jaymand, et al. "Essential oil and essential oil extractors." Iranian Journal of Medicinal and Aromatic Plants Research 1.9: 1-161 (in Persian)

[20] Chemat, Farid, and Chahrazed Boutekedjiret. "Extraction//steam distillation." Reference Module in Chemistry, Molecular Sciences and Chemical Engineering; Elsevier: Amsterdam, The Netherlands (2015): $1-12$. 
[21] Noori, Hossein, and Maryam Khajenoori. "Subcritical Water Extraction of Essential Oils from Matricaria Chamomilla L." International Journal of Engineering 26.5 (2013): 489-494.

[22] Burger, Pauline, et al. "Extraction of natural fragrance ingredients: history overview and future trends." Chemistry \& Biodiversity 16.10 (2019): e1900424.

[23] Douglas, M., J. Heyes, and B. Smallfield. "Herbs, spices and essential oils: post-harvest operations in developing countries." UNIDO and FAO 61 (2005).

[24] Babu, Kiran GD, and V. K. Kaul. "Variation in essential oil composition of rose-scented geranium (Pelargonium sp.) distilled by different distillation techniques." Flavour and fragrance journal 20.2 (2005): 222-231.

[25] Yildirim, Ali, et al. "The variation of antioxidant activities and chemical composition of essential oils of Teucrium orientale L. var. orientale during harvesting stages." Flavour and Fragrance Journal 19.5 (2004): $367-372$.

[26] Gavahian, Mohsen, et al. "Comparison of ohmic-assisted hydrodistillation with traditional hydrodistillation for the extraction of essential oils from Thymus vulgaris L." Innovative Food Science 63 Emerging Technologies 14 (2012): 85-91.

[27] Perino-Issartier, Sandrine, et al. "A comparison of essential oils obtained from lavandin via different extraction processes: Ultrasound, microwave, turbohydrodistillation, steam and hydrodistillation." Journal of Chromatography A 1305 (2013): 41-47.

[28] CAO, Lv, et al. "Study on techniques of turbo-hydrodistillation extraction of essential oil from Kaempferia galangal with response surface methodology." China Food Additives 11 (2015): 9

[29] Jaimand, K., and M. B. Rezaee. "Investigation extraction by two different apparatus and effects of essential oils on content and constituents of Tripleurospermum disciforme (CA Mey) Schultz-Bip." In Natural Sciences (2003).

[30] Oktavianawati, Ika. "Essential Oil Extraction of Cananga odorata Flowers using Hydrodistillation and Steam-Water Distillation Processes." IOP Conference Series: Materials Science and Engineering . Vol. 833. No. 1. IOP Publishing, 2020.

[31] Alam, P. N., H. Husin, and T. M. Asnawi. "Extraction of citral oil from lemongrass (Cymbopogon citratus) by steam-water distillation technique." IOP Conference Series: Materials Science and Engineering . Vol. 345. No. 1. IOP Publishing, 2018.

[32] Reverchon, E., and F. Senatore. "Isolation of rosemary oil: comparison between hydrodistillation and supercritical CO2 extraction." Flavour and fragrance journal 7.4 (1992): 227-230.

[33] Sell, Charles, and Charles Sell. Perfumery materials of natural origin . Royal Society of Chemistry: Cambridge, UK, 1999.

[34] Boutekedjiret, C., et al. "Extraction of rosemary essential oil by steam distillation and hydrodistillation." Flavour and Fragrance Journal 18.6 (2003): 481-484

[35] Cassel, E., et al. "Steam distillation modeling for essential oil extraction process." Industrial crops and products 29.1 (2009): 171-176.

[36] Vian, Maryline Abert, et al. "Microwave hydrodiffusion and gravity, a new technique for extraction of essential oils." Journal of chromatography a 1190.1-2 (2008): 14-17.

[37] Talanda, Colin Erlo. The design, construction and testing of a mobile essential oil distillation unit . Diss. 2005.

[38] Weiss, Edward A. Essential oil crops . Cab International, 1997. 
[39] Ferhat, Mohamed A., Brahim Y. Meklati, and Farid Chemat. "Comparison of different isolation methods of essential oil from Citrus fruits: cold pressing, hydrodistillation and microwave "dry'distillation." Flavour and Fragrance Journal 22.6 (2007): 494-504.

[40] Velluti, Andrea. Ecofisiologia de especies de Fusarium productoras de fumonisinas, zearalenona y deoxinivalenol en maiz: aceites esenciales como inhibidores fungicos . Universitat de Lleida, 2002.

[41] Arnodou, J. F. "The taste of nature; industrial methods of natural products extraction." a conference organized by the Royal Society of Chemistry in Canterbury . 1991.

[42] Soto, C., R. Chamy, and M. E. Zuniga. "Enzymatic hydrolysis and pressing conditions effect on borage oil extraction by cold pressing." Food chemistry 102.3 (2007): 834-840.

[43] Anwar, F., et al. "Enzyme-aided cold pressing of flaxseed (Linum usitatissimum L.): Enhancement in yield, quality and phenolics of the oil." Grasas y aceites 64.5 (2013): 463-471.

[44] Burbott, Alice J., and W. David Loomis. "Effects of light and temperature on the monoterpenes of peppermint." Plant physiology 42.1 (1967): 20-28.

[45] Lawrence, BRIAN M. "The isolation of aromatic materials from natural plant products." A manual on the essential oil industry (1995): 57-154.

[46] Li, X-M., et al. "Extraction of Cuminum cyminum essential oil by combination technology of organic solvent with low boiling point and steam distillation." Food chemistry 115.3 (2009): 1114-1119

[47] Areias, Filipe, et al. "Flavonoids and phenolic acids of sage: influence of some agricultural factors." Journal of agricultural and food chemistry 48.12 (2000): 6081-6084.

[48] Pizzale, Lorena, et al. "Antioxidant activity of sage (Salvia officinalis and S fruticosa) and oregano (Origanum onites and O indercedens) extracts related to their phenolic compound content." Journal of the Science of Food and Agriculture 82.14 (2002): 1645-1651.

[49] Koşar, M., H. J. D. Dorman, and Raimo Hiltunen. "Effect of an acid treatment on the phytochemical and antioxidant characteristics of extracts from selected Lamiaceae species." Food chemistry 91.3 (2005): 525-533.

[50] Lago, Sara, et al. "Improved concentration of citrus essential oil by solvent extraction with acetate ionic liquids." Fluid Phase Equilibria 361 (2014): 37-44.

[51] Durling, Nicola E., et al. "Extraction of phenolics and essential oil from dried sage (Salvia officinalis) using ethanol-water mixtures." Food chemistry 101.4 (2007): 1417-1424.

[52] Manniche, Lise. Sacred luxuries: fragrance, aromatherapy, and cosmetics in ancient Egypt . Cornell University Press, 1999.

[53] Engineers, N. B. "The Complete Technology Book on Flavours, Fragrances and Perfumes." (2007).

[54] Handa, S. S. "An overview of extraction techniques for medicinal and aromatic plants." Extraction technologies for medicinal and aromatic plants 1 (2008).

[55] De Silva, Tuley, ed. A manual on the essential oil industry . United Nations Industrial Development Organization, 1995.

[56] Chemat, Farid, Maryline Abert Vian, and Giancarlo Cravotto. "Green extraction of natural products: concept and principles." International journal of molecular sciences 13.7 (2012): 8615-8627.

[57] Herrero, Miguel, Alejandro Cifuentes, and Elena Ibañez. "Sub-and supercritical fluid extraction of functional ingredients from different natural sources: Plants, food-by-products, algae and microalgae: A review." Food chemistry 98.1 (2006): 136-148. 
[58] Pourmortazavi, Seied Mahdi, and Seiedeh Somayyeh Hajimirsadeghi. "Supercritical fluid extraction in plant essential and volatile oil analysis." Journal of chromatography A 1163.1-2 (2007): 2-24.

[59] Hawthorne, Steven B., et al. "Comparison of hydrodistillation and supercritical fluid extraction for the determination of essential oils in aromatic plants." Journal of Chromatography A 634.2 (1993): 297-308.

[60] Capuzzo, Andrea, Massimo E. Maffei, and Andrea Occhipinti. "Supercritical fluid extraction of plant flavors and fragrances." Molecules 18.6 (2013): 7194-7238.

[61] Vági, E., et al. "Essential oil composition and antimicrobial activity of Origanum majorana L. extracts obtained with ethyl alcohol and supercritical carbon dioxide." Food research international 38.1 (2005): 51-57.

[62] Lasekan, O., and S. Azeez. "Chemo-preventive Activities of Common Vegetables' Volatile Organic Compounds (VOCs)." Pharm Anal Acta 5.306 (2014): 2.

[63] Pereira, Camila G., and M. Angela A. Meireles. "Economic analysis of rosemary, fennel and anise essential oils obtained by supercritical fluid extraction." Flavour and Fragrance Journal 22.5 (2007): 407-413

[64] Reverchon, E., G. Della Porta, and F. Senatore. "Supercritical CO2 extraction and fractionation of lavender essential oil and waxes." Journal of Agricultural and Food Chemistry 43.6 (1995): 1654-1658.

[65] Ayala, Rogelio Soto, and MD Luque De Castro. "Continuous subcritical water extraction as a useful tool for isolation of edible essential oils." Food chemistry 75.1 (2001): 109-113.

[66] Rovio, S., et al. "Extraction of clove using pressurized hot water." Flavour and Fragrance Journal 14.6 (1999): 399-404.

[67] Moyler, David A. "Extraction of essential oils with carbon dioxide." Flavour and fragrance journal 8.5 (1993): 235-247.

[68] Chen, Chu Chin, et al. "Pungent compounds of ginger (Zingiber officinale Roscoe) extracted by liquid carbon dioxide." Journal of Agricultural and Food Chemistry 34.3 (1986): 477-480

[69] De Castro, MD Luque, M. M. Jiménez-Carmona, and V. Fernandez-Perez. "Towards more rational techniques for the isolation of valuable essential oils from plants." TrAC Trends in Analytical Chemistry 18.11 (1999): 708-716.

[70] Eikani, Mohammad H., Fereshteh Golmohammad, and Soosan Rowshanzamir. "Subcritical water extraction of essential oils from coriander seeds (Coriandrum sativum L.)." Journal of Food Engineering 80.2 (2007): 735-740.

[71] Vladić, Jelena, et al. "Comparative Study of Subcritical Water and Microwave-Assisted Extraction Techniques Impact on the Phenolic Compounds and 5-Hydroxymethylfurfural Content in Pomegranate Peel." Plant Foods for Human Nutrition (2020): 1-8.

[72] Vinatoru, Mircea. "An overview of the ultrasonically assisted extraction of bioactive principles from herbs." Ultrasonics sonochemistry 8.3 (2001): 303-313

[73] Chemat, Farid, et al. "Ultrasound assisted extraction of food and natural products. Mechanisms, techniques, combinations, protocols and applications. A review." Ultrasonics sonochemistry 34 (2017): $540-560$

[74] Romanik, Grażyna, et al. "Techniques of preparing plant material for chromatographic separation and analysis." Journal of biochemical and biophysical methods 70.2 (2007): 253-261.

[75] Alissandrakis, E., et al. "Ultrasound-assisted extraction of volatile compounds from citrus flowers and citrus honey." Food chemistry 82.4 (2003): 575-582.

[76] Selvamuthukumaran, M., and John Shi. "Recent advances in extraction of antioxidants from plant by-products processing industries." Food Quality and Safety 1.1 (2017): 61-81. 
[77] Sarlaki, et al. Green Technologies: "An Innovative and Sustainable Approaches in the Extraction of Bioactive Compounds from Agro-Food Wastes". Green Chemistry and Sustainable Technology 1.1 (2019):1332 (in Persian)

[78] Puértolas, Eduardo, Mohamed Koubaa, and Francisco J. Barba. "An overview of the impact of electrotechnologies for the recovery of oil and high-value compounds from vegetable oil industry: Energy and economic cost implications." Food Research International 80 (2016): 19-26.

[79] Barba, Francisco J., et al. "Green alternative methods for the extraction of antioxidant bioactive compounds from winery wastes and by-products: A review." Trends in Food Science 8 Technology 49 (2016): 96-109.

[80] Richter, Bruce E., et al. "Accelerated solvent extraction: a technique for sample preparation." Analytical chemistry 68.6 (1996): 1033-1039.

[81] Barba, Francisco J., et al. "Effect of alternative physical treatments (ultrasounds, pulsed electric fields, and high-voltage electrical discharges) on selective recovery of bio-compounds from fermented grape pomace." Food and Bioprocess Technology 8.5 (2015): 1139-1148.

[82] 71Pronyk, C., and G. Mazza. "Design and scale-up of pressurized fluid extractors for food and bioproducts." Journal of Food Engineering 95.2 (2009): 215-226

[83] Barba, F. J., et al. "Implementation of emerging technologies." Innovation strategies in the food industry . Academic Press, 2016. 117-148

[84] Cacace, J. E., and G. Mazza. "Pressurized low polarity water extraction of lignans from whole flaxseed." Journal of Food Engineering 77.4 (2006): 1087-1095.

[85] Hayes, Maria, ed. Marine bioactive compounds: sources, characterization and applications . Springer Science \& Business Media, 2011

[86] Ganzler, Katalin, András Salgó, and Klára Valkó. "Microwave extraction: A novel sample preparation method for chromatography." Journal of chromatography A 371 (1986): 299-306.

[87] Périno-Issartier, S. "Zill e, H., Abert-Vian, M., Chemat, F., 2011. Solvent free Microwave-Assisted extraction of antioxidants from sea buckthorn (Hippophae rhamnoides) food by-Products." Food Bioprocess Technol 4.6: 1020-1028.

[88] Ameer, Kashif, Hafiz Muhammad Shahbaz, and Joong-Ho Kwon. "Green extraction methods for polyphenols from plant matrices and their byproducts: A review." Comprehensive Reviews in Food Science and Food Safety 16.2 (2017): 295-315.

[89] Chemat, F., and X. Fernandez. "La Chimie des Huiles Essentielles: Tradition et Innovation." Vuibert: Paris, France (2012).

[90] Corney, Alan. Atomic and laser spectroscopy . Oxford: Clarendon Press, 1978.

[91] Tomaniova, M., et al. "Microwave-assisted solvent extraction - a new method for isolation of polynuclear aromatic hydrocarbons from plants." Journal of Chromatography A 827.1 (1998): 21-29.

[92] Abert-Vian, Maryline, Mohamed Elmaataoui, and Farid Chemat. "A novel idea in food extraction field: study of vacuum microwave hydrodiffusion technique for by-products extraction." Journal of food engineering 105.2 (2011): 351-360.

[93] Golmakani, Mohammad-Taghi, and Karamatollah Rezaei. "Microwave-assisted hydrodistillation of essential oil from Zataria multiflora Boiss." European Journal of Lipid Science and Technology 110.5 (2008): $448-454$ 
[94] Bendahou, M., et al. "Antimicrobial activity and chemical composition of Origanum glandulosum Desf. essential oil and extract obtained by microwave extraction: Comparison with hydrodistillation." Food Chemistry 106.1 (2008): 132-139

[95] Chemat, F., et al. "Microwave accelerated steam distillation of essential oil from lavender: A rapid, clean and environmentally friendly approach." Analytica Chimica Acta 555.1 (2006): 157-160

[96] Ferhat, Mohamed A., et al. "Rapid extraction of volatile compounds using a new simultaneous microwave distillation: solvent extraction device." Chromatographia 65.3-4 (2007): 217-222

[97] Sahraoui, Naima, et al. "Valorization of citrus by-products using Microwave Steam Distillation (MSD)." Innovative food science \& emerging technologies 12.2 (2011): 163-170

[98] Barišić, Veronika, et al. "Does High Voltage Electrical Discharge Treatment Induce Changes in Tannin and Fiber Properties of Cocoa Shell?." Foods 9.6 (2020): 810

[99] Roselló-Soto, Elena, et al. "High voltage electrical discharges, pulsed electric field, and ultrasound assisted extraction of protein and phenolic compounds from olive kernel." Food and Bioprocess Technology 8.4 (2015): 885-894.

[100] Li, Zongming, Yang Fan, and Jun Xi. "Recent advances in high voltage electric discharge extraction of bioactive ingredients from plant materials." Food chemistry 277 (2019): 246-260

[101] Ali, Nasser A. Awadh, et al. "Chemical composition and biological activities of essential oils from the oleogum resins of three endemic Soqotraen Boswellia species." Records of Natural Products 2.1 (2008): 6

[102] da Silva, Eduardo R., et al. "Essential oils of Protium spp. samples from Amazonian popular markets: Chemical composition, physicochemical parameters and antimicrobial activity." Journal of Essential Oil Research 25.3 (2013): 171-178

[103] Figueredo, G., et al. "A research on the composition of essential oil isolated from some aromatic plants by microwave and hydrodistillation." Journal of Food Biochemistry 36.3 (2012): 334-343

[104] Boutekedjiret, C., et al. "Extraction of rosemary essential oil by steam distillation and hydrodistillation." Flavour and Fragrance Journal 18.6 (2003): 481-484

[105] Charles, Denys J., and James E. Simon. "Comparison of extraction methods for the rapid determination of essential oil content and composition of basil." Journal of the American Society for Horticultural Science 115.3 (1990): 458-462.

[106] Charles, Denys J., and James E. Simon. "Comparison of extraction methods for the rapid determination of essential oil content and composition of basil." Journal of the American Society for Horticultural Science 115.3 (1990): 458-462.

[107] Atti-Santos, Ana Cristina, et al. "Extraction of essential oils from lime (Citrus latifolia Tanaka) by hydrodistillation and supercritical carbon dioxide." Brazilian Archives of Biology and Technology 48.1 (2005): 155-160.

[108] Yamini, Yadollah, et al. "Comparison of essential oil compositions of Salvia mirzayanii obtained by supercritical carbon dioxide extraction and hydrodistillation methods." Food Chemistry 108.1 (2008): 341346.

[109] Guan, Wenqiang, et al. "Comparison of essential oils of clove buds extracted with supercritical carbon dioxide and other three traditional extraction methods." Food Chemistry 101.4 (2007): 1558-1564

[110] Samejo, Muhammad Qasim, et al. "Comparison of chemical composition of Aerva javanica seed essential oils obtained by different extraction methods." Pak J Pharm Sci 26.4 (2013): 757-760 
[111] Liu, Yanqing, Hongwu Wang, and Jiali Zhang. "Comparison of MAHD with UAE and hydrodistillation for the analysis of volatile oil from four parts of Perilla frutescens cultivated in southern China." Analytical letters 45.13 (2012): 1894-1909.

[112] Moreira, Sílvia A., et al. "Effect of emergent non-thermal extraction technologies on bioactive individual compounds profile from different plant materials." Food Research International 115 (2019): 177-190

[113] Wollinger, Alexander, et al. "Antioxidant activity of hydro distillation water residues from Rosmarinus officinalis L. leaves determined by DPPH assays." Comptes Rendus Chimie 19.6 (2016): 754-765

[114] Quezada-Moreno, W. F., et al. "Extraction and chemical characterization of the essential oil of Tagetes pusilla, in fresh and stored samples." Afinidad 76.588 (2019).

[115] Perineau, Francis, Leguet Ganou, and Gérard Vilarem. "Studying production of lovage essential oils in a hydrodistillation pilot unit equipped with a cohobation system." Journal of Chemical Technology $\&$ Biotechnology 53.2 (1992): 165-171.

[116] Gounaris, Y. "Biotechnology for the production of essential oils, flavours and volatile isolates. A review." Flavour and fragrance journal 25.5 (2010): 367-386.

[117] Gupta, C., D. Prakash, and S. Gupta. "A biotechnological approach to microbial based perfumes and flavours." J. Microbiol. Exp 3.1 (2015)

[118] Bomgardner, Melody M. "The sweet smell of microbes." Chemical 85 Engineering News 90.29 (2012): $25-29$.

[119] Moreno, Paulo RH, Robert van der Heijden, and Robert Verpoorte. "Cell and tissue cultures of Catharanthus roseus: a literature survey." Plant cell, tissue and organ culture 42.1 (1995): 1-25.

[120] Habibi Khaniani Behnam, et al." Production of Secondary Metabolites and drugs through Tissue and Plant Cells Culture" (2005): 1-6 (in Persian)

[121] Roja, G. Biotechnology of indigenous medicinal plants . Diss. Ph. D Thesis. Bombay University. Bombay, 1994 .

[122] Sevón, Nina, and Kirsi-Marja Oksman-Caldentey. " Agrobacterium rhizogenes-mediated transformation: root cultures as a source of alkaloids." Planta Medica 68.10 (2002): 859-868.

[123] Flores, Hector E., Jorge M. Vivanco, and Victor M. Loyola-Vargas. "'Radicle'biochemistry: the biology of root-specific metabolism." Trends in plant science 4.6 (1999): 220-226.

[124] Garavaglia, Juliano, et al. "Bioconversion of L-phenylalanine into 2-phenylethanol by Kluyveromyces marxianus in grape must cultures." World Journal of Microbiology and Biotechnology 23.9 (2007): 1273-1279.

[125] Zheng, Lirong, et al. "Production of vanillin from waste residue of rice bran oil by Aspergillus niger and Pycnoporus cinnabarinus." Bioresource Technology 98.5 (2007): 1115-1119

[126] Dörnenburg, Heike, and Dietrich Knorr. "Production of phenolic flavor compounds with cultured cells and tissues of Vanilla species." Food Biotechnology 10.1 (1996): 75-92.

[127] Plant Callus Cultures of Smyrnium perfoliatum L." Journal of Essential Oil Research 4.4 (1992): 431-432

[128] Reil, Gerold, and Ralf G. Berger. "Variation of chlorophyll and essential oils in photomixotrophic cell cultures of Coleonema album (Thunb.)." Journal of plant physiology 150.1-2 (1997): 160-166

[129] Cotton, C. M., J. W. Gramshaw, and L. V. Evans. "The effect of $\alpha$-naphthalene acetic acid (NAA) and benzylaminopurine (BAP) on the accumulation of volatile oil components in cell cultures of tarragon (Artemisia dracunculus)." Journal of experimental botany 42.3 (1991): 377-386. 
[130] Chung, I. S., et al. "Continuous suspended cell culture of Mentha piperita in cell-recycled air-lift bioreactor." Biotechnology techniques 8.11 (1994): 789-792

[131] Matsuda, Yoshinori, et al. "A hairy root culture of melon produces aroma compounds." Journal of agricultural and food chemistry 48.4 (2000): 1417-1420

[132] Santos, Paula M., et al. "Essential oils from hairy root cultures and from fruits and roots of Pimpinella anisum." Phytochemistry 48.3 (1998): 455-460

[133] Tiansheng, Lu, et al. "Sesquiterpenes and thiarubrines from Ambrosia trifida and its transformed roots." Phytochemistry 33.1 (1993): 113-116.

[134] Santos, Pedro AG, et al. "Hairy root cultures of Anethum graveolens (dill): establishment, growth, time-course study of their essential oil and its comparison with parent plant oils." Biotechnology letters 24.12 (2002): 1031-1036

[135] Farbood, Mohamad I., and Brian J. Willis. "Production of $\gamma$-decalactone." U.S. Patent No. 4,560,656. 24 Dec. 1985.

[136] Zheng, Lirong, et al. "Production of vanillin from waste residue of rice bran oil by Aspergillus niger and Pycnoporus cinnabarinus." Bioresource Technology 98.5 (2007): 1115-1119.

[137] Lin, Shen-Juh, Shiow-Ling Lee, and Cheng-Chun Chou. "Effects of various fatty acid components of castor oil on the growth and production of $\gamma$-decalactone by Sporobolomyces odorus." Journal of fermentation and bioengineering 82.1 (1996): 42-45

[138] Dickschat, Jeroen S., et al. "Biosynthesis and identification of volatiles released by the myxobacterium Stigmatella aurantiaca." ChemBioChem 6.11 (2005): 2023-2033.

[139] Kang, Seung-Mi, et al. "Biotransformation and impact of ferulic acid on phenylpropanoid and capsaicin levels in Capsicum annuum L. cv. P1482 cell suspension cultures." Journal of agricultural and food chemistry 53.9 (2005): 3449-3453.

[140] Zhu, W., G. Asghari, and G. B. Lockwood. "Factors affecting volatile terpene and non-terpene biotransformation products in plant cell cultures." Fitoterapia 71.5 (2000): 501-506.

[141] Mitsuhashi, Katsuhisa, and Makoto Iimori. "Method for producing lactone." U.S. Patent No. 7,129,067. 31 Oct. 2006.

[142] Vane, Leland M. "A review of pervaporation for product recovery from biomass fermentation processes." Journal of Chemical Technology $\& 3$ Biotechnology: International Research in Process, Environmental E Clean Technology 80.6 (2005): 603-629.

[143] Georgiev, Milen I., Atanas I. Pavlov, and Thomas Bley. "Hairy root type plant in vitro systems as sources of bioactive substances." Applied microbiology and biotechnology 74.6 (2007): 1175.

[144] Liu, Zhibin, Roland Weis, and Anton Glieder. "Enzymes from higher eukaryotes for industrial biocatalysis." Food technology and biotechnology 42.4 (2004): 237-249

[145] Schreier, P. "Enzymes and flavour biotechnology." Biotechnology of aroma compounds . Springer, Berlin, Heidelberg, 1997. 51-72.

[146] De Carvalho, Carla CCR, and M. Manuela R. da Fonseca. "Biotransformation of terpenes." Biotechnology advances 24.2 (2006): 134-142.

[147] Giri, Archana, et al. "Biotransformations using plant cells, organ cultures and enzyme systems: current trends and future prospects." Biotechnology advances 19.3 (2001): 175-199.

[148] Elvers, K. T., and H. M. Lappin-Scott. "Encyclopedia of microbiology." (2000). 
[149] Yang, Yea-Tyng, George N. Bennett, and Ka-Yiu San. "Genetic and metabolic engineering." Electronic Journal of Biotechnology 1.3 (1998): 20-21

[150] Bomgardner, Melody M. "The sweet smell of microbes." Chemical \& Engineering News 90.29 (2012): $25-29$.

[151] Kang, Seung-Mi, et al. "Biotransformation and impact of ferulic acid on phenylpropanoid and capsaicin levels in Capsicum annuum L. cv. P1482 cell suspension cultures." Journal of agricultural and food chemistry 53.9 (2005): 3449-3453.

[152] Mulder-Krieger, T. H., et al. "Production of essential oils and flavours in plant cell and tissue cultures. A review." Plant cell, tissue and organ culture 13.2 (1988): 85-154

[153] Hausler, Alex. "Microbial production of natural flavors." AsM News (1997): 551-559

[154] de Carvalho, Carla CCR, and M. Manuela R. da Fonseca. "Towards the bio-production of trans-carveol and carvone from limonene: induction after cell growth on limonene and toluene." Tetrahedron: Asymmetry 14.24 (2003): 3925-3931.

[155] Larroche, C., C. Cruely, and J-B. Gros. "Fed-batch biotransformation of $\beta$-ionone by Aspergillus niger." Applied microbiology and biotechnology 43.2 (1995): 222-227

[156] Hong, Yeong-Ching Albert, et al. "Production of aroma compounds from strawberry cell suspension cultures by addition of precursors." Plant cell, tissue and organ culture 21.3 (1990): 245-251.

[157] Almosnino, A. M., M. Bensoussan, and J. M. Belin. "Unsaturated fatty acid bioconversion by apple pomace enzyme system. Factors influencing the production of aroma compounds." Food chemistry 55.4 (1996): 327-332.

[158] Cass, B. J., et al. "Production of tomato flavor volatiles from a crude enzyme preparation using a hollow-fiber reactor." Biotechnology and bioengineering 67.3 (2000): 372-377

[159] Lee, M. H., et al. "Bioconversion of d-Limonene to Oxygenated Compounds by Endogenous Enzymes of the Citrus Peel." JOURNAL-CHINESE AGRICULTURAL CHEMICAL SOCIETY 37 (1999): 1-19.

[160] Yoshida, Aya, et al. "Vanillin formation by microbial amine oxidases from vanillylamine." Journal of fermentation and bioengineering 84.6 (1997): 603-605

[161] de Kraker, Jan-Willem, et al. "Hydroxylation of sesquiterpenes by enzymes from chicory (Cichorium intybus L.) roots." Tetrahedron 59.3 (2003): 409-418.

[162] Waché, Yves, et al. "Role of $\beta$-oxidation enzymes in $\gamma$-decalactone production by the yeast Yarrowia lipolytica." Applied and environmental microbiology 67.12 (2001): 5700-5704.

[163] Frost, John W. "Synthesis of vanillin from a carbon source." U.S. Patent No. 6,372,461. 16 Apr. 2002.

[164] Alberts, Bruce, et al. "Studying gene expression and function." Molecular Biology of the Cell. 4th edition. Garland Science, 2002.

[165] Zuker, Amir, et al. "Modification of flower color and fragrance by antisense suppression of the flavanone 3-hydroxylase gene." Molecular Breeding 9.1 (2002): 33-41

[166] Beale, Michael H., et al. "Aphid alarm pheromone produced by transgenic plants affects aphid and parasitoid behavior." Proceedings of the National Academy of Sciences 103.27 (2006): 10509-10513. 